\title{
Selected Annotated Bibliography on the . Geochemistry of Gold
}

$\begin{array}{llllllllllllllllllll}\text { G E O L O G I C A L S U R E E B U L L E T I N } 1337 & \text { S }\end{array}$

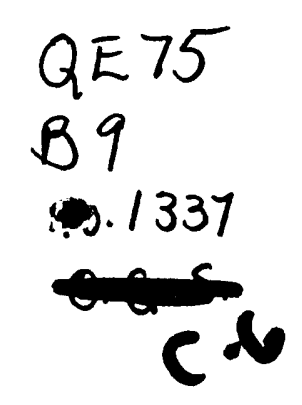




\section{Selected Annotated}

\section{Bibliography on the}

\section{Geochemistry of Gold}

By MARGARET COOPER

G E O L O G I C A L S U R V E Y B U L L E T I N 1337

Approximately 200 references dealing with the genesis and geochemistry of gold and with geochemical prospecting for gold deposits

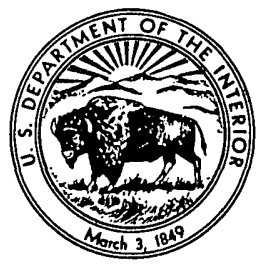




\section{UNITED STATES DEPARTMENT OF THE INTERIOR}

ROGERS C. B. MORTON, Secretary

\section{GEOLOGICAL SURVEY}

William T. Pecora, Director

Library of Congress catalog-card No. 77-611048

For sale by the Superintendent of Documents, U.S. Government Printing Office Washington, D.C. 20402 - Price 35 cents (paper cover) 


\section{CONTENTS}

Page

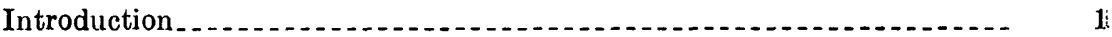

General geochemistry ........

Major gold-bearing minerals.

Geological distribution of gold........ 3 :

Explanation of bibliographic references.................. 4

Explanation of index headings_............ 4

Serial list.................. 4

Bibliography

Author index

Subject index 


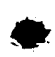

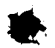




\title{
SELEGTED ANNOTATED BIBLIOGRAPHY ON THE GEOCHEMISTRY OF GOLD
}

\author{
By Margaret Cooper
}

\section{INTRODUCTION}

This bibliography of about 200 selected references furnishes information on source materials dealing with the genesis and geochemistry of gold and geochemical prospecting for gold deposits. The geological literature has been covered fairly completely through early 1969; a few references published in late 1969 and in early 1970 have also been included.

In selecting the references, an attempt has been made to include mainly papers having the best summaries of early and recent work on a given subject rather than all the available papers related to that subject. Many of the articles cited contain excellent reference lists of the earlier literature. The most comprehensive of these are indicated in the bibliography section by the listing of the approximate number of references or by the general notation "bibliography" in their citations.

Few references are listed that deal solely with geological occurrences of gold unless they provide an up-to-date review of gold occurrence in areas not covered in the older literature or are related to some phase of the geochemistry of gold. References are accompanied by either a very brief annotation or a more detailed abstract; all references are indexed.

Brief descriptions of the geochemical and geological nature of gold follow and are accompanied by explanations of the arrangement of the bibliographic references and the index, a chart of the major gold-bearing minerals, and a serial list.

Acknowledgments. - The author is indebted to colleagues at the Geological Survey for recommendations and assistance, particularly, to Michael Fleischer for background material from the Chemical Abstracts file and to Robert S. Jones for many helpful suggestions. 


\section{GENERAL GEOCHEMISTRY}

Gold has the atomic number 79 and an atomic weight of 197.0. It consists of a single isotope and belongs to group IB in the periodic table. It is strongly siderophilic, somewhat chalcophilic, and tends to be concentrated in the metallic phase of meteorites with somewhat lower concentrations in the sulfide phase and much lower concentrations in the silicate phase. In nature, gold occurs mainly as the native metal and in various alloys, particularly alloys of silver and intermetallic compounds. It can also form solid solutions with silver, copper, nickel, platinum, and palladium. Although free gold is common in sulfides, it only combines directly with sulfur in the telluride-sulfide, nagyagite. Several gold tellurides are known but no gold selenides have been reported. More complete descriptions of the geochemistry of gold may be found in standard works on geochemistry such as:

Goldschmidt, V. M., and Muir, Alex, ed., [1958], Geochemistry: Oxford, England, Clarendon Press, $730 \mathrm{p}$.

Krauskopf, K. B., 1967, Introduction to geochemistry: New York, McGraw-Hill Book Co., 721 p.

Mason, B. H., 1966, Principles of geochemistry [3d ed.]: New York, John Wiley and Sons, Inc., $329 \mathrm{p}$.

Rankama, K. K., and Sahama, T. G., 1950, Geochemistry: Chicago, Univ. Chicago Press, $912 \mathrm{p}$.

Descriptions may also be found in some of the references included in this bibliography, especially U.S. Geological Survey Circular 612 by R. S. Jones and Michael Fleischer and in V. P. Sokoloff's translation of "Geochemistry of gold" by O. E. Zvyagintsev.

\section{MAJOR GOLD-BEARING MINERALS}

The following chart on the major gold-bearing minerals is based on a table in U.S. Geological Survey Circular 612.

Native gold

(Au), specific gravity 19.3 (pure) decreases as silver content increases.

Native gold varieties:

Electrum

$(\mathrm{Au}, \mathrm{Ag})$, argentian gold containing less than 20 percent Ag.

Porpetzite................ (Au, Pd), palladian gold containing 5-10 percent $\mathrm{Pd}$.

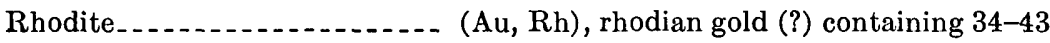
percent $\mathrm{Rh}$.

Auricupride

Or cuproauride, considered to be a solid solution of gold in copper, near $\mathrm{AuCu}_{3}$ in composition. 
Aurosmirid, aurosmiridium -... Equals aurian osmiridium, probably $Q$ mixture containing 19.3 percent Au.

Silver._..... (Ag, Au), aurian silver, containing 0-50 percent $\mathrm{Au}$.

Küstelite . . . . . . . . . . . . . Equals aurian silver.

Gold-amalgam .................... $\mathrm{Au}_{2} \mathrm{Hg}_{3}$ (?), containing 34.2-41.6 percent $\mathrm{Au}$.

Maldonite.............................. $\mathrm{Au}_{2} \mathrm{Bi}$, containing 64.5-65.1 percent $\mathrm{Au}$ and 34.9-35.5 percent $\mathrm{Bi}$.

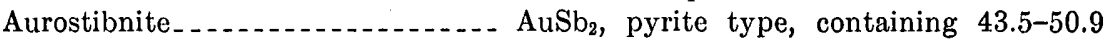
percent $\mathrm{Au}$.

Krennerite......................... AuTe $e_{2}$, containing 30.7-43.9 percent $\mathrm{Au}$.

Müllerine.................. Equals krennerite.

Speculite . . . . . . . . . . . . Equals krennerite(?).

Calaverite . . . . . . AuTe $\mathrm{A}_{2}$, containing 39.2-42.8 percent $\mathrm{Au}$.

Coolgardite . . . . . . . . . Equals a mixture of calaverite, coloradoite ( $\mathrm{HgTe})$, and sylvanite.

Sylvanite......................... ( $\mathrm{Au}, \mathrm{Ag}) \mathrm{Te}_{2}$, the $\mathrm{Au}$ : $\mathrm{Ag}$ ratio usually nearly $1: 1$; that is, $\mathrm{AgAuTe}_{4}$, containing 24.2529.9 percent Au.

Goldschmidtite .............. Equals sylvanite.

Kostovite................... $\mathrm{CuAuTe}_{4}$, containing 25.2 percent $\mathrm{Au}$.

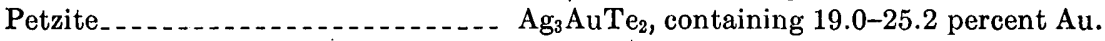

Antamokite.............. Equals a mixture of petzite and altaite.

Hessite............. $\mathrm{Ag}_{2} \mathrm{Te}$, containing as much as 4.7 percent $\mathrm{Au}$.

Montbrayite.................... $\mathrm{Au}_{2} \mathrm{Te}_{3}$, containing 38.6-44.3 percent $\mathrm{Au}$.

Nagyagite $\ldots \ldots \ldots \mathrm{Pb}_{5} \mathrm{Au}(\mathrm{Te}, \mathrm{Sb})_{4} \mathrm{~S}_{5-8}($ ?), containing7 . 4-10.2 percent Au.

Silberphyllinglanz ...

Blatterine . . . . . . . . . Equals nagyagite.

Aurobismuthinite..... $(\mathrm{Bi}, \mathrm{Au}, \mathrm{Ag})_{5} \mathrm{~S}_{6}(?)$, probably a mixture of 12.3 percent $\mathrm{Au}$ and 2.3 percent $\mathrm{Ag}$.

\section{GEOLOGICAL DISTRIBUTION OF GOLD}

The abundance of gold in the earth's crust is estimated to be between 0.001 and $0.006 \mathrm{ppm}$ (parts per million). Commonly gold occurs as deposits in quartz veins in, or associated with, volcanic or plutonic rocks and as an accessory mineral in base-metal sulfide deposits. Gold is also abundant in secondary deposits such as placers. It occurs rarely in telluride-type deposits. Individual gold deposits are found in the form of pyrosomatic and hydrothermal deposits, magmatic segregations, pegmatites, and placers and range in age from Precambrian to Quaternary. Gold deposits are found throughout the world, mostly in areas where intrusive rocks are intermediate or silicic in composition. The references on abundance of gold included in this bibliography indicate the wide range of materials in which trace amounts of gold are present in nature. 


\section{EXPLANATION OF BIBLIOGRAPHIC REFERENCES}

Each bibliographic reference is listed alphabetically under the last name of the author or, in multiple-author papers, under the last name of the senior author. Each reference includes the title, publication source, and year of publication. Names of serial publications are abbreviated in these references in the style used by the U.S. Geological Survey in its "Bibliography of North American Geology" and "Geophysical Abstracts" and are listed alphabetically in both abbreviated and full form in the accompanying serial list. Titles of articles published in foreign languages using the Roman alphabet are listed both in the original language and in English. Titles for which the original is written in the Cyrillic alphabet are listed both in transliterated form (following the system used by the U.S. Board on Geographic Names) and in English. For a foreign language reference for which an English translation or an English abstract is available, the citation includes the publication source of both the original and the English version. Translations listed as manuscript copies in the citations have not been formally published but may be borrowed on interlibrary loan from the U.S. Geological Survey Library.

\section{EXPLANATION OF INDEX HEADINGS}

Three orders of headings are used in each index set. The main headings are mostly subjects such as abundance, geochemical prospecting, and geochemistry. There are a few cross-references for geographical areas which are important for information on occurrences. Subj cts such as biogeochemical methods, indicator elements, indicator plants, and ore guides are used as second-order headings under the main heading, geochemical prospecting. Subjects such as alteration, fineness, genesis, mineral associations, mobility, and solubility are used as second-order headings under the main heading, geochemistry. The third-order headings give specific information related to their first- and second-order headings. One or more index sets may be used depending on the amount of pertinent information in a given reference.

\section{SERIAL LIST}

Acad. Sci. URSS Comptes Rendus (Doklady)-Académie des Sciences URSS Comptes Rendus (Doklady). Translated version of Akademiya Nauk SSSR Doklady prepared by the Akademiya Nauk. Moscow, U.S.S.R.

Acad. Sci. USSR Doklady, Earth Sci. Sec.-Doklady of the Academy of Sciences USSR, Earth Sciences Sections, which supersede the earlier Geological Science and Geochemical Sections. English translation of geological sections 
of Akademiya Nauk SSSR Doklady, Moscow, U.S.S.R., by the American Geological Institute, Washington, D.C.

Akad. Nauk Armyan. SSR Izv.-Akademiya Nauk Armyanskoy SSR Izvestiya. Yerevan, U.S.S.R.

Akad. Nauk SSSR Doklady-Akademiya Nauk SSSR Doklady. Moscow, U.S.S.R.

Akad. Nauk SSSR Izv. Ser. Geol.-Akademiya Nauk SSSR Izvestiya, Seriya Geologicheskaya. Moscow, U.S.S.R.

Akad. Nauk SSSR Sibirsk. Otdeleniye, Geologiya i Geofizika-Akademiya Nauk SSSR Sibirskoye Otdeleniye, Geologiya i Geofizika. Novosibirsk, U.S.S.R.

Am. Inst. Mining and Metall. Engineers Trans.-Transactions of the American Institute of Mining and Metallurgical Engineers. New York, N.Y.

Amsterdam Univ. Geol. Inst. Mededel.-Amsterdam Universiteit, Geologisch Instituut Mededeling. Amsterdam, Netherlands.

Bibliography and Index of Geology [exclusive of North America] Monthly Abs.Bibliography and Index of Geology [exclusive of North America] Monthly Abstracts. Geological Society of America. Boulder, Colorado.

California Div. Mines and Geology Bull.-California Division of Mines and Geology Bulletin. San Francisco, Calif.

Canada Geol. Survey Mem.-Geological Survey of Canada Memoir. Ottawa, Ontario, Canada.

Canada Geol. Survey Paper-Geological Survey of Canada Paper. Ottawa, Ontario, Canada.

Canadian Inst. Mining and Metallurgy Trans.-Transactions of the Canadian Institution of Mining and Metallurgy and of the Mining Society of Nova Scotia. Montreal, Quebec, Canada.

Canadian Mining and Metall. Bull.-Canadian Mining and Metallurgical Bulletin. Canadian Institution of Mining and Metallurgy. Montreal, Quebec, Canada.

Canadian Mining Jour.-Canadian Mining Journal. National Business Publications, Ltd. Gardenvale, Quebec, Canada.

Chamber of Mines Jour.-Journal of the Chamber of Mines of Rhodesia. Salisbury, Rhodesia.

Chem. Abs.-Chemical Abstracts. Chemical Abstracts Service, Ohio State University. Columbus, Ohio.

Chem. Geology-Chemical Geology. Elsevier Publishing Company. Amsterdam, : Netherlands.

Colorado School Mines Mineral Industries Bull.-Colorado School of Mines Mineral Industries Bulletin. Golden, Colo.

Earth and Planetary Sci. Letters-Earth and Planetary Science Letters. North Holland Publishing Company. Amsterdam, Netherlands.

Econ. Geology-Economic Geology and the Bulletin of the Society of Economic Geologists. Mount Pleasant, Mich.

Eng. and Mining Jour.-Engineering and Mining Journal. McGraw-Hill Publishing Co. New York, N.Y.

[France] Bur. Recherches Géol. et Minières Bull.-Bulletin du Bureau de Recherches Géologiques et Minières. Paris, France.

Geochemistry-Geochemistry [superseded by Geochemistry International]. English translation of Geokhimiya, Akademiya Nauk SSSR, by the Geochemical Society, American Geological Institute, Washington, D.C.

$416-169-71-2$ 
Geochemistry Internat.-Geochemistry International [formerly Geochemistry]. English translation of Geokhimiya, Akademiya Nauk SSSR, by the Geochemical Society, American Geological Institute. Washington, D.C.

Geochim. et Cosmochim. Acta-Geochimica et Cosmochimica Acta. Pergamon Press. Oxford, England.

Geokhimiya-Geokhimiya. Akademiya Nauk SSSR. Moscow, U.S.S.R.

Geol. Soc. South Africa Trans.-Transactions of the Geological Society of South Africa. Johannesburg, South Africa.

Geologiya Rudnykh Mestorozhdeniy-Geologiya Rudnykh Mestorozhdeniy. Akademiya Nauk SSSR. Moscow, U.S.S.R.

Inst. Mining and Metallurgy Trans.-Transactions of the Institution of Mining and Metallurgy. London, England.

Internat. Geology Rev.-International Geology Review. American Geological Institute. Washington, D.C.

Jour. Geology-Journal of Geology. University of Chicago Press. Chicago, Ill.

Marine Biol. Assoc. United Kingdom Jour.-Journal of the Marine Biological Association of the United Kingdom. Cambridge University Press. London, England.

Metals and Minerals Rev.-Metals and Minerals Review. Onkar Nath Pandeya at Nagarjun Press. Calcutta, India.

Michigan Acad. Sci., Arts, and Letters Papers-Papers of the Michigan Academy of Science, Arts, and Letters. Ann Arbor, Mich.

Mineralium Deposita-Mineralium Deposita. Society for Geology Applied to Mineral Deposits. Berlin and Heidelberg, Germany, and New York, N.Y.

Mines Mag.-Mines Magazine. Colorado School of Mines Alumni Association. Denver, Colo.

Mining Mag. [London]-Mining Magazine. The Mining Journal Ltd. London, England.

Moskov. Univ. Vestnik, Ser. 4 Geologiya-Vestnik Moskovskogo Universiteta, Seriya 4 Geologiya. Moscow, U.S.S.R.

Oregon Dept. Geology and Mineral Industries Bull.-Oregon Department of Geology and Mineral Industries Bulletin. Portland, Oreg.

Pacific Northwest Metals and Minerals Conf., 3d, Portland, Oreg., Proc.-Pacific Northwest Metals and Minerals Conference, 3d, Proceedings. Portland, Oregon.

Queens Coll. City Univ. New York, Geology Dept., Geol. Bull.-Queens College of the City University of New York, Geology Department, Geological Bulletin. New York, N.Y.

Soc. Française Minéralogie et Cristallographie Bull.-Bulletin de la Société Française de Minéralogie et de Cristallographie. Paris, France.

Soc. Mining Engineers Preprint-Preprint of the Society of Mining Engineers. Society of Mining Engineers of AIME. New York, N.Y.

South Carolina Div. Geology Bull.-South Carolina Division of Geology Bulletin. South Carolina State Development Board. Columbia, S.C.

Sovetskaya Geologiya-Sovetskaya Geologiya. Ministerstvo Geologii SSSR. Moscow, U.S.S.R.

U.S. Bur. Mines Heavy Metals Program Tech. Prog. Rept.-U.S. Bureau of Mines Heavy Metals Program Technical Progress Report. Washington, D.C.

U.S. Bur. Mines Inf. Circ.-U.S. Bureau of Mines Information Circular. Washington, D.C. 
U.S. Geol. Survey Bull.-United States Geological Survey Bulletin. Washington D.C.

U.S. Geol. Survey Circ.-United States Geological Survey Circular. Washington, D.C.

U.S. Geol. Survey Mineral Inv. Resource Map-United States Geological Survey Mineral Investigations Resource Map. Washington, D.C.

U.S. Geol. Survey Open-File Rept.-United States Geological Survey OpenFile Report. Washington, D.C.

U.S. Geol. Survey Prof. Paper-United States Geological Survey Professional Paper. Washington, D.C.

Uzbek. Geol. Zhur.-Uzbekskiy Geologicheskiy Zhurnal. Akademiya Nauk Uzbekskoy SSR. Tashkent, Uzbek S.S.R.

Virginia Div. Mineral Resources, Mineral Resources Rept.-Virginia Division of Mineral Resources, Mineral Resources Report. Virginia Department of Conservation and Economic Development. Charlottesville, Va.

Washington State Inst. Technology Circ.-Washington State Institute of Technology Circular. Washington State University. Pullman, Wàsh.

Witwatersrand Univ. Econ. Geology Research Unit Inf. Circ--University of Witwatersrand Economic Geology Research. Unit Information Circular. Johannesburg, South Africa.

Zeitsch. Angew. Chemie-Zeitschrift für Angewandte Chemie. Verlag Chemie. Berlin, Germany.

Zeitsch. Gesell. Erdkunde Berlin, Ergänzungsheft-Zeitschrift der Gesellschaft für Erdkunde zu Berlin, Ergänzungsheft. Berlin, Germany.

\section{BIBLIOGRAPHY}

Ref.

1 Andrew-Jones, D. A. The application of geochemical techniques to mineral exploration: Colorado School of Mines Mineral Industries Bull., v. 11, no. 6, 31 p., 53 references, 1968.

This general review includes a discussion of gold with emphasis on the principles governing its abundance, distribution, associations, and behavior under varied physical and chemical conditions. Gold was found to be very stable in the zone of weathering where it is a major element with quartz but was found to be unstable as a trace element in micaceous deposits. The abundance of gold was reported to be 0.001 parts per million (ppm) in the earth's crust, $0.001 \mathrm{ppm}$ in igneous rocks in general, $0.01 \mathrm{ppm}$ in felsic rocks, $0.035 \mathrm{ppm}$ in mafic rocks, and $0.1 \mathrm{ppm}$ in ultramafic rocks.

2 Anoshin, G. N.; Potap'yev, V. V. Zoloto $\mathrm{v}$ granitakh Kolyvanskogo (Altay) i Khangilay-Shilinskogo (Zabaykal'ye) massivov (po dannym radioaktivatsionnogo analisa) [Gold in granites of the Kolyvan' (Altay) and Khangilay-Shilinskiy (Transbaykalya) massifs (according to radioactivation analysis data) ]: Geokhimiya, no. 9, p. 1070-1074, 17 references, 1966; English translation in Geochemistry Internat., v. 3 , no. 5 , p. $850-854,1966$.

Radioactivation analysis of gold in hydrothermally altered granites of two multiple-phase massifs gave an average of $0.0012 \mathrm{~g}$ per ton in both massifs, but higher concentrations of gold existed in parts where early 
Rer.

muscovitization had occurred. The gold content in rock-forming minerals was $0.0008 \mathrm{~g}$ per ton in quartz and $0.0003 \mathrm{~g}$ per ton in feldspar. There is no evidence of change in gold content from one phase to the other.

3 Antrobus, E. S. A. The origin of the auriferous reefs of the Witwatersrand system: Geol. Soc. South Africa Trans., v. 59, p. 1-15, 16 references, 1956; discussion, p. 17-22, 1956.

New evidence is presented in favor of the alluvial origin of the gold in the auriferous reefs of the Witwatersrand system. The Basal Reef of the Orange Free State sometimes consists of two distinct reefs of different, though nearly contemporaneous, age, the younger being disconformable upon the older. The distribution of the gold in each reef indicates that the gold was probably present at the time the reefs were formed and that the younger reef incorporated gold initially deposited within the older reef. (From author's abs.)

4 Antweiler, J. C.; Love, J. D. Gold-bearing sedimentary rocks in northwest Wyoming-A preliminary report: U.S. Geol. Survey Circ. 541, 12 p., 13 references, 1967.

Analyses of 1,200 samples and 750 panned concentrates were made on thick sequences of gold-bearing quartzite conglomerate in the latest Cretaceous and Tertiary formations and the Quaternary gravels derived from them. Gold content averages in parts per billion in bulk rock were: Harebell Formation (latest Cretaceous), 65; Pinyon Conglomerate (Paleocene), 86; Fort Union Formation (Paleocene), 35; earliest(?) Eocene conglomerate, 94; Wind River Formation (early Eocene), 222; Pass Peak Formation (middle(?) Eocene), 47; Miocene(?) conglomerate, 65; and Quaternary deposits, 103. The volume of over 50 cubic miles and presence of aboveaverage grades, which possibly indicate local concentrations, may make it a valuable resource. The amount of placer gold present is negligible.

5 Aripova, Kh.; Talipov, R. M. Osobennosti kontsentratsii zolotav pochvakh i rasteniyakh yuzhnoy chasti Tamdynskikh gor [Concentration of gold in soils and plants in the southern part of the Tamdynsk Mountains]: Uzbek. Geol. Zhur., v. 10, no. 3, p. 45-51, 10 references, 1966; English translation, 14 p., June 15, 1967.

The concentration of gold in plant ash and in soils over ore-free and ore-bearing zones is described for the Bessapan-Sugralin belt of the Tamdynsk Mountains, U.S.S.R. Ferula (Ferula sp.) averaged $16.3 \mathrm{ppm}$ Au over the ore zone and $1.5 \mathrm{ppm} \mathrm{Au}$ over the ore-free zone. Saltwort (Salsola subaphylla) averaged $13.2 \mathrm{ppm}$ Au over the ore zone. Wormwood (Artemesia terras alba) averaged $28.8 \mathrm{ppm} \mathrm{Au}$ over the ore zone and $4.0 \mathrm{ppm} \mathrm{Au}$ over the ore-free zone. The ore-free zone soil cover contained 0.0 to $0.15 \mathrm{ppm}$ $\mathrm{Au}$ at depths of $0-110 \mathrm{~cm}$. The ore zone soil cover contained 0.00 to traces to $0.4 \mathrm{ppm} \mathrm{Au}$ at depths of $0-200 \mathrm{~cm}$.

6 Augustithis, S. S. On the textures and paragenesis of the gold-quartztourmaline veins of Ondonoc, W. Ethiopia [with German abs.]: Mineralium Deposita, v. 3, no. 1, p. 48-55, 7 references, 1967.

The gold-quartz-tourmaline veins of Ondonoc occur in diorites and schists and follow the non-distortion planes of the theoretical strain ellipsoid. 
Ref.

Textural studies reveal a sequence of crystallization phases. In addition to an early prismatic tourmaline, a late phase "metasomatic" tourmalinization is recognized. The gold occurs mainly with pyrite which, in turn, is considered to belong to a late phase with ankerite and prochlorite. Micromylonitization and other tectonic influences are recognizable and bodies of the country rock, e.g. schists and tourmalinefels, are engulfed and tectonically mobilized within these veins, thus rendering the interpretation of the paragenesis more difficult. (Author's abs.)

7 Badalov, S. T. O roli preobladayushchikh komponentov $\mathrm{v}$ geokhimii vtorosterennykh $\mathrm{i}$ redkikh elementov rudnykh mestorozhdeniy [The role of major components in the geochemistry of minor and rare elements of ore deposits]: Geokhimiya, no. 9, p. 1168-1170; 3 references, 1965; English translation in Geochemistry Internat., v. 2, no. 5, p. 857-860, 1965.

Finely disseminated native gold in the copper-molybdenum deposits 0 the Almalyk district, U.S.S.R., was most abundant in pyrite, a low-grade mineral. Other minerals generally carrying high concentrations of minor elements are too sparse here to be dominant carriers. Chalcopyrite, normally a good concentrator of gold, contains $22 \mathrm{~g}$ per ton but has only 26 percent of the total, whereas pyrite with only $3 \mathrm{~g}$ per ton carries more than 72 percent.

8 Badalov, S. T.; Badalova, R. P. Nekotorye zakonomernosti raspredeleniya zolota $\mathrm{i}$ serebra $\mathrm{v}$ glavneyshikh rudnykh mineralakh endogennykh mestorozhdeniy Karamazara i zapadnogo Uzbekistana [Some regularities of distribution of gold and silver in the principal ore minerals of hypogene deposits of Karamazar and western Uzbekistan]: Geokhimiya, no. 7, p. 777-785, 31 references, 1967; English translation in Geochemistry Internat., v. 4, no. 4, p. 660-668, 1967.

Distribution of gold and silver in sulfides of ore deposits depends on content of sulfides, sequence of deposition, and affinity of the elements for certain ore minerals. Gold content decreases from earlier to later facies while silver content increases. The gold-silver ratio is characteristic of a given mineralization, the maximum in Karamazar being $1: 28$, whereas it may be 1:1 and even 2:1 in West Uzbekistan. Variations may be due to differences in the roles of enclosing rocks. Study of distribution of gold and silver in endogene deposits may serve as an ore guide to the presence of gold deposits.

9 Badalova, R. P.; Badalov, S. T. O probnosti zolota iz endogennykh mestorozhdeniy i rudoproyavleniy Uzbekistana [The standard of gold from hypogene ore deposits and occurrences of Uzbekistan]: Akad. Nauk. SSSR Doklady, v. 173, no. 4, p. 914-916, 15 references, 1967; English translation in Acad. Sci. USSR Doklady, Earth Sci. Sec., v. 173, nos. 1-6, p. 194-197, 1967.

Gold fineness has about the same mean in host rocks of arenaceous mica schists and of intermediate to acidic effusive rocks, namely, 539-928, but averages only about 500-750 in miscellaneous effusive rocks. Purity appears to have increased with increasing sulfide content, whereas ore content increased with increasing free $\mathrm{SiO}_{2}$ content in veins and altered rocks. 
Ref.

10 Badalova, R. P.; Paley, L. Z. Osnovnyye cherty metallogenii zolota v zapadnom Uzbekistane [Main features in metallogeny of gold in western Uzbekistan]: Geologiya Rudnykh Mestorozhdeniy, v. 7, no. 5, p. 38-46, 10 references, 1965; English rev. in Econ. Geology, v. 63, no. 7, p. 852, 1968.

Gold mineralization occurs in anticlinoria near granitoid intrusions but at varying distances from them. Deposition of gold began in the first stage of mineralization, reached its maximum in the second stage, and is affiliated with the granodiorites, which consist of $30-50$ percent plagioclase, $15-30$ percent microcline, and amphibole. Gold mineralization is associated with quartz and sulfides.

11 Barker, Fred. Gold investigations in Precambrian clastic and pelitic rocks, southwestern Colorado and northern New Mexico: U.S. Geol. Survey Bull. 1272-F, p. F1-F22, 23 references, 1969.

Fossil placer gold deposits were sampled in the Precambrian conglomerate and quartzite of Needles Mountains, Colo., and the Picuris Range and Tusas Mountains, N. Mex. Tre rocks proved to contain less than $0.1 \mathrm{ppm}$ $\mathrm{Au}$ and apparently were derived from a terrane containing virtually no gold. A comparison with the Rand conglomerates indicated that they differed from the U.S. deposits in (1) having detrital gold, platinumgroup minerals, and uraninite, (2) being free of carbon, (3) having much less detrital vein quartz, and (4) having escaped hydrothermal alteration during which pyrite and other sulfides were formed.

12 Barnett, Paul R.; Skinner, Dwight L.; Huffman, Claude, Jr. Determination of gold, platinum, and palladium by a combined fire-assay, ionexchange, and spectrochemical technique in Geological Survey research 1968: U.S. Geol. Survey Prof. Paper 600-C, p. C161-C163, 8 references, 1968.

The techniques of fire assay, ion exchange, and spectroscopy are combined to determine the existence of gold, platinum, and palladium in ores. After silica is added to the resin containing these metals, the mixture is ignited and analyzed spectrochemically. These techniques were used on copper ore from Montana and dunite-chromite ore from Philippines; they produced limits of detection of at least $0.03 \mathrm{ppm}$ for Au. (From authors' abs.)

13 Bateman, Alan M. The precious metals-Gold, Chap. 12, in Economic mineral deposits [2d ed.]: New York, John Wiley and Sons, p. 234-239, 419-454, 28 references, 1950.

Gold lode and placer deposits are among the economic mineral deposits discussed.

14 Beevers, J. R. A method for the determination of the gold content of of samples by solvent extraction and atomic absorption spectrometry: Eeon. Geology, v. 62, no. 3, p. 426-428, 5 references, 1967.

The method of gold determination by a combination of solvent-extraction and atomic absorption spectrophotometry techniques is rapid, cheap, suffieiently sensitive to be useful in geochemical prospecting, and completely free from interference. Its lower detection limit is 0.02 micrograms.

15 Berg, Henry C.; Cobb, Edward H. Metalliferous lode deposits of Alaska: U.S. Geol. Survey Bull. 1246, 254 p., 315 references, 1967.

Gold is among the metals discussed in this summary on the metalbbearing lodes of Alaska. The summary is based on reports from Federal 
Ref.

and State agencies published before August 31, 1965, and deals with the geology, structural or stratigraphic control, host rock, mode of origin, kinds of minerals, past production, and extent of exploration. The maps indicate 692 localities where metalliferous deposits were found. These include 1,739 mines and prospects, of which 821 are described or cited in the text.

16 Bilibin, Yu. A. Metallogenicheskiye provintsii i metallogenicheskiye epokhi [Metallogenetic provinces and metallogenetic epochs]: Moscow, Gosgeoltekhizdat, 86 p., 1955; English translation in Queens Coll. City Univ. New York, Geology Dept. Geol. Bull. 1, 35 p., 1968.

This review of the world's metallogenetic provinces and the times of their formation includes discussions of various types and ages of gold ore deposits and their mineral associations. It furnishes good background material on metallogenetic problems applying to other metals as well as gold.

17 Borovitskiy, V. P.; Miller, A. D.; Shemyakin, V. N. Opredeleniye malykh kolichestv zolota $\mathrm{v}$ prirodnykh vodakh Aldanskogo rayona (Determination of minute amounts of gold in natural waters of the Aldan region]: Geokhimiya, no. 4, p. 483-488, 10 references, 1966; English translation in Geochemistry Internat., v. 3, no. 2, p. 371-377, 1966.

Gold in natural waters is determined by preliminary concentration of gold with calomel and subsequent spectral or colorimetric analysis of the calcinated concentrate. Sensitivity of the method is $0.001 \mathrm{ppm}$ Au per liter. Gold content per liter in natural waters of the Aldan region, U.S.S.R., was found to be 0.1 to $10 \mathrm{~g}$ in pit waters in gold mines, trace to $1 \mathrm{~g}$ in spring waters in gold mines, and traces and 0.03 to $0.2 \mathrm{~g}$ in streams near gold-ore :deposits. The method is also applicable to silver, titanium, arsenic, tin, antimony, and tellurium.

18 Borovitskiy, V. P.; Shemyakin, V: N. Opyt primeneniya karbonatnoy s'yemki pri poiskakh zolotorudnykh mestorozhdeniy $\mathrm{v}$ Aldanskom rayone [Trial application of the carbonate survey in prospecting for gold in the Aldan areal: Sovetskaya Geologiya, no. 10, p. 145-146, 1 reference, 1965; English translation in Internat. Geology Rev., v. 8, no: 9 , p. $1037-1038,1966$.

High carbonate content in soil is a guide to gold at depth in the Koltykon gold field in the Aldan area, U.S.S.R. This type of survey may prove useful in other areas in gold prospecting.

19 Bowen, H. J. M. The uptake of gold by marine sponges: Marine Biol. Assoc. United Kingdom Jour., v. 48, no. 2, p. 275-277, 4 references, 1968.

Gold content of dried marine sponges was determined by neutron activation analysis. One sample from the coast of Plymouth, England, contained $0.126 \mathrm{ppm}$ or $12.6 \times 10^{-8} \mathrm{~g}$ per $\mathrm{g} \mathrm{Au}$, whereas five from Hawaii ranged from 0.018 to $0.055 \mathrm{ppm}$ or $1.8-5.5 \times 10^{-8} \mathrm{~g}$ per $\mathrm{g} \mathrm{Au}$. The difference is possibly caused by the high gold content of inshore water in the English Channel.

20 Bowen, H. J. M. Trace elements in biochemistry: London and New York, Academic Press, 241 p., references (p. 211-234), 1966.

This book summarizes results of earlier biogeochemical studies on gold content and is used in lieu of many individual papers (including some by Vinogradov and other Russian authors), which are cited in the extensive 
Ref.

bibliography. Abundance of gold averaged $0.004 \mathrm{ppm}$ in igneous rocks in general, $0.005 \mathrm{ppm}$ in sedimentary rocks, and less than $0.125 \mathrm{ppm}$ in coal. Figures for the gold content of sea water, plant ash, and animal ash are also included. The gold content of plant ash was $0.012 \mathrm{ppm}$ for algae and less than $0.00045 \mathrm{ppm}$ for angiosperms. The gold content for animal ash was coelenterata $0.007 \mathrm{ppm}$, mollusca $0.008 \mathrm{ppm}$, crustacea $0.0005 \mathrm{ppm}$, echinodermata $0.03\left(\right.$ ?) $\mathrm{ppm}$, pisces $0.0003 \mathrm{ppm}$, porifera in $\mathrm{SiO}_{2} 0.01 \mathrm{ppm}$, mammalia, less than $0.009 \mathrm{ppm}$, mammalia, bones (apatite) $0.016 \mathrm{ppm}$, and mammalia, dry tissues 0.0001 to less than $0.5 \mathrm{ppm}$.

21 Boyle, Robert W. Elemental associations in mineral deposits and indicator elements of interest in geochemical prospecting: Canada Geol. Survey Paper 68-58, 45 p., 1969.

The most important types of gold deposits are: (1) gold-silver quartz veins in volcanic and sedimentary rocks, (2) gold-silver telluride or selenide deposits, mainly veins in or associated with volcanic rocks, (3) gold deposits in skarn bodies, (4) quartz-pebble conglomerates like the Rand type, (5) placers and residual concentrations, and (6) various types of $\mathrm{Cu}, \mathrm{Pb}, \mathrm{Zn}$, and $\mathrm{Ni}$ deposits. Main associated elements are $\mathrm{Ag}, \mathrm{As}, \mathrm{S}$, and $\mathrm{Fe}$ although some deposits, mostly Tertiary, include considerable $\mathrm{Sb}, \mathrm{Pb}, \mathrm{Zn}, \mathrm{Cu}$, and $\mathrm{Cd}$. The Au/Ag ratio is high in the Precambrian and low, usually less than 1, in the Tertiary deposits. Wallrock alteration is apt to include one or more of the following: albitization, silicification, pyritization, adularization, and carbonitization.

22 Boyle, Robert W. Geochemical prospecting-Retrospect and prospect: Canadian Inst. Mining and Metallurgy Trans., v. 70, p. 1-6, 2 references, 1967; Canada Geol. Survey Paper 66-54, p. 30-43, 1967.

The author reviews the history of geochemical prospecting. Rapid developments of modern methods are based on recognition of primary and secondary dispersion halos, and development of spectrographic, colorimetric, and gas chromatography methods and of polyethylene laboratory ware which facilitated field analyses. Future research should focus on definition of geochemical provinces; methods of discovering large low-grade deposits, deeply buried deposits, and outlining primary halos; relation of size and intensity of anomalies to grade of deposits; and refinement of biogeochemical methods.

23 Boyle, Robert W. The geology, geochemistry, and origin of the gold deposits of the Yellowknife district [with French abs.]: Canada Geol. Survey Mem. 310, 193 p., 188 references, 1960 [1961]; discussion by George W. McConnell in Econ. Geology, v. 59, no. 2, p. 328-330, 1964; reply by author, no. 6 , p. 1176-1177, 1964 .

The ore bodies of the Giant, Con-Rycon, and Negus mines produced most of the gold and occur as quartz lenses in extensive chlorite schist shear zones cutting greenstones. The Ptarmigan mine and other similar deposits are ore bodies occurring in quartz lenses developed along faults, in drag folds, and other structures in highly folded and contorted sedimentary rocks. (From author's introd.)

24 Boyle, Robert W. The source of elements in epigenetic mineral depositsA metallogenetic concept for prospecting: Canadian Mining Jour., v. 90, no. 4, p. 104-107, 8 references, 1969.

Principal factors involved in the concentration of elements in epigenetic deposits are the source, mode of transportation, presence of suitable struc- 
Ref.

tures or chemically favorable rocks, and mechanism for precipitation. In the case of gold, the source may be sulfide schists or black schists and shales or volcanic and various igneous or igneous-type rocks. In prospecting it is suggested that the source rock be identified, the host rock be identified; and geochemical and geophysical surveys be carried out along belts of favorable host rocks to locate the lodes.

25 Brokaw; Albert D. The secondary precipitation of gold in ore bodies: Jour. Geology, v. 21, p. 251-267, about 30 references, 1913.

Ferrous compounds derived from partial oxidation of iron sulfides are considered the most important agents in precipitation of gold from solutions of water circulating through ore bodies. Less commonly, siderite, the ironbearing calcite, may be the precipitating agent. In rare cases where gold is in a solution with manganous salts, contact with the country rock may neutralize the acids present and cause gold precipitation. No attempt is made here to explain gold precipitation from alkaline sulfide solutions.

Brokaw, Albert D. The solution of gold in the surface alterations of ore bodies: Jour. Geology, v. 18, p. 321-326, about 10 references, 1910 .

Dilution of natural solutions of ferric salts probably has a very slight solvent effect on gold. In the presence of manganese dioxide, (1) no increased gold solution occurs, unless chlorides also are present, (2) mixtures of ferric sulfate, sulfuric acid and sodium chloride in concentrations common in mine waters dissolve gold readily, (3) free hydrochloric acid has a much greater solvent effect than the same amount of chloride in a ferric chloride solution, and (4) influence of ferrous salts in suppressing solubility of gold is negligible. Solution of gold is practically limited to the oxidized zone.

Bronshteyn, B. M.; Karpova, A. S. Osvyazi magnitnykh anomaliy s zolotonosnost'yu (basseyn r. Kolymy) [Relationship between magnetic anomalies and occurrence of gold (Kolyma River basin)]: Sovetskaya Geologiya, no. 2, p. 127-132, 4 references, 1968; English translation in Internat. Geology Rev., v. 11, no. 1, p. 21-23, 1969.

In the basin studied, more than 72 percent of known gold placers occur within contours of positive magnetic anomalies, which in turn occupy only about 30 percent of the region. The gold lode deposits found also appear to be within $500 \mathrm{~m}$ or so of the magnetic anomalies but frequently seem to be lower than average in gold content because the gold content of the placers in the anomalies is quite high.

28 Brooks, Howard C.; Ramp, Len. Gold and silver in Oregon: Oregon Dept. Geology and Mineral Industries Bull. 61, 337 p., 121 references, 1968.

Describes the history and nature of the major gold lode and placer deposits of Oregon with emphasis on and detailed studies of the gold deposits in the Blue Mountains gold belt, the Klamath Mountains area, and the Western Cascades section of the Cascade Range.

29 Bugel'skaya, L. V., compiler; Perel'man, A. I., editor. Geokhimicheskiye metody poiskov rudnykh mestorozhdeniy-Bibliograficheskiy ukazatel' literatury, 1925-1963 gg., Pt. 2, Gidrogeokhimicheskiye poiski, biogeokhimicheskiye poiski . . . [Geochemical methods of exploration for ore deposits-Bibliography and index of literature, 1925-1963, Pt. 2, Hydrogeochemical exploration, biogeochemical exploration....]: Moscow, Nauka, 95 p., 1967. 
Ref:

The bibliography and index cover literature from worldwide publications as well as the Russian periodicals. Gold is among the elements studied. The publication lacks annotations but has author, geographical, and subject indexes and a serial list.

30 Buryak, V. A. Endogennaya zonal'nost' orudeneniya v drevnikh zolotonosnykh provintsiyakh Sibiri [Hypogene zoning of mineralization in the old gold provinces of Siberia]: Akad. Nauk SSSR Doklady, v. 173, no. 5, p. 1170-1172, 14 references, 1967; English translation in Acad. Sci. USSR Doklady, Earth Sci. Sec., v. 173, nos. 1-6, p. 212$214,1967$.

Relation to degree of metamorphism of host rocks rather than to specific magmatic complexes determines the mineralization in the Lena gold fields, U:S.S.R. Banded distribution of metamorphosed zones around an ultrametamorphosed core which consists of metamorphic granite pegmatites and is related to an underlying deep fracture zone suggests that zonation was caused by ascending solutions from the deep zone.

31 Buryak, V. A. Novyy tip zolotogo orudeneniya v Lenskoy zolotonosnoy provintsii [A new type of gold mineralization in the Lena gold province]: Akad. Nauk SSSR Doklady, v. 169, no. 1, p. 163-166, 7 references, 1966; English translation in Acad. Sci. USSR Doklady, Earth Sci. Sec., v. 169, nos. 1-6, p. 14-16, 1967.

The new Karolon-type gold deposits are found in Proterozoic to Cambrian igneous, volcanic, and sedimentary rocks in the form of quartz veins in zones of dense sulfide dissemination. The gold is finely dispersed and closely associated with sulfides and has an average tenor of $10-20 \mathrm{~g} \mathrm{Au}$ per ton. Types of ore textures present include brecciform, drusy, geode, crustification, drusy-massive, banded, and massive. Types of wallrock alteration include silicification, carbonitization, sericitization, propylitization, and beresitization, the latter being hydrothermal alteration of acidic rocks with pyritization and the formation of sometimes auriferous quartz veins.

Buryak, V. A. Zolotorudnyye formatsii Lenskogo zolotonosnogo rayona [Gold ore formations of the Lena gold-bearing area], in Endogennyye rudnyye formatsii Sibiri i Dal'nego Vostoka [Endogene ore formations of Siberia and the Far East]: Moscow, Nauka, p. 145-155, 8 references, 1966; English translation in Internat. Geology Rev., v. 9, no. 12, p. 1553-1559, 1967.

The sources of the rich Lena gold placers are quartz-vein formations and veinlets-impregnation sulfide formations. The gold-sulfide mineralization is related to regional metamorphism of late Proterozoic age and has occurred mainly in rocks of lower grade metamorphism (greenschists). The veinletsimpregnation type is somewhat older and was formed at the closing stages of folding whereas the quartz-vein type formed at the end stages of folding. The source of the metals may have been sediments with primary sedimentary gold and sulfides which were mobilized and redeposited by metamorphic and hydrothermal solutions. (From author's abs.)

33 Buryak, V. A.; Kashcheyeva, T. V.; Khmelevskaya, N. M. O vliyanii sostava vmeshchayushchikh porod na razvitiye dokembriyskogo zolotogo orudeneniya (Patomskoye nagor'ye) [Influence of host rock composition on the development of Precambrian gold mineralization 
Ref.

(Patom Highlands)]: Akad. Nauk SSSR Doklady, v. 169, no. 2, p. 405-408, 11 references, 1966; English translation in Acad. Sci. USSR Doklady, Earth Sci. Sec., v. 169, nos. 1-6, p. 44-47, 1967.

The Precambrian gold ore deposits are made up of gold-bearing, sulfidepoor hypothermal quartz veins and zones of gold-sulfide dissemination in highly deformed sedimentary host rocks of late Precambrian age, which indicates that the process of ore genesis was closely related to latest Precambrian regional metamorphism, ultrametamorphism, and palinogenesis. The gold veins formed in quartzose-sericitic shale and oligomict sandstone. Few formed in the carbonate rocks; placers from these rocks also had no gold.

34 Cabri, Louis J. Phase relations in the Au-Ag-Te system and their mineralogical significance: Econ. Geology, v. 60, no. 8, p. 1569-1606, 55 references, 1965.

A systematic investigation of the physical conditions of formation and the phase relations in the Au-Ag-Te system provides a new basis for interpretation of their mineral assemblages in ores. Krennerite is interpreted as a single mineral entity rather than a polymorph of $\mathrm{AuTe}_{2}$, whereas hessite and petzite are each characterized by three polymorphs. The experimental data can be applied to studies of ore deposits in the following ways: (1) for the coexisting phases, limits of solid solution may be used to make estimates of the temperature of formation, (2) stability limits determined for some assemblages can give a measure of the physical conditions prevailing during deposition, and (3) a natural mineral assemblage with the same phases as a synthetic ore may suggest phase equilibrium.

35 Cannon, Helen L.; Shacklette, Hansford T.; Bastron, Harry. Metal absorption by Equisetum (Horsetail): U.S. Geol. Survey Bull. 1278-A, p. A1-A21, 31 references, 1968.

Plant samples were analyzed for 28 elements. Equisetum was found to be a better accumulator of zinc and other elements than of gold and proved to be lower in content of all metals than other types of plants in areas studied. In conterminous U.S., it contained 0.1 to $0.4 \mathrm{ppm} \mathrm{Au}$ and in Mc Grath and Red Devil areas, Alaska, 0.1 to $0.5 \mathrm{ppm} \mathrm{Au.}$

36 Chamber of Mines Journal. Antheaps a guide to mineral deposits: Chamber of Mines Jour., v. 10, no. 12, p. 29, 1968; v. 11, no. 3, p. 16, 1969; v. 11 , no. 9 , p. $19,1969$.

This summary of an unpublished speech by W. F. West to the local branch of the Rhodesian Scientific Association suggests what might be considered as a new type of ore guide to mineral deposits, especially in desert areas. Termites in the area build heaps with drainage funnels down to the water level. When the water level drops, the termites continue down into the sulfide zone. Heaps built over gold mines of a known grade have been found to agree in gold content with the average known value of the mines when a specific factor is applied. The Rhodesian government is making investigations of the method.

37 Chernyayev, A. M.; Chernyayeva, L. E.; Yeremeyeva, M. N.; Andreyev, M. I. Gidrogeokhimiya zolota [Hydrogeochemistry of gold]: Geokhimiya, no. 4, p. 449-459, 36 references, 1969; English translation in Geochemistry Internat., v. 6, no. 2, p. 348-358, 1969 [1970]. 
Ref:

This review of the literature and original analyses of the gold content of natural supergene ground waters gave an abundance of less than 0.1 to 4 $\mathrm{ppb}$ gold. The amount of gold did not depend on the chemical composition of the waters for equal concentrations of gold were found in bicarbonate, sulfate, and chloride waters and in neutral, weakly acid, and weakly alkaline waters. Gold migrates in supergene ground waters in ionic or colloidal forms, in soluble complexes, and in mechanical suspensions depending on the physicochemical environment. A useful guide in hydrogeochemical prospecting for gold deposits may be the pattern of gold distribution in ground water, the principal criteria being high contents of gold, silver, arsenic, and bismuth.

38 Chow, A.; Beamish, F. E. A comparison of methods for determining gold in ores: Canadian Mining Jour., v. 88, no. 6, p. 66-69, 13 references, 1967.

Fire assay is most rapid and efficient method for multiple routine analyses of ores. Wet extraction method permits determination of gold in ores without special equipment and the evaluation of ores which present collection problems for fire assay. Neutron activation method is efficient and has the advantage of detecting amounts of less than 0.005 micrograms of gold.

39 Chukhrov, F. V. O migratsii zolota $\mathrm{v}$ zone okisleniya [Migration of gold in the oxidation zone]: Akad. Nauk SSSR Izv., Ser. Geol., no. 4, p. 117-125, 33 references, 1947; English translation, 18 p. ms.

The author reviews the various theories dealing with the migration of gold in the zone of oxidation and concentration, of which the basis is migration of gold in ionic form. He concludes that gold in the zone of oxidation is carried in iodine or bromide compounds in ionic form.

40 Clark, Sandra H. B.; Condon, William H.; Foster, Helen L.; Hoare, Joseph M. Geochemical data in the Sikonsina Pass area [Alaska], in Some shorter mineral resource investigations in Alaska: U.S. Geol. Survey Circ. 615, p. 21-25, 23 references, 1969.

Anomalous concentrations of lead, gold, copper, and molybdenum were detected locally in analyses of stream sediments from this area, which is largely underlain by metasedimentary rocks. Gold content in stream sediments ranged from less than 0.02 to $0.04 \mathrm{ppm}$ whereas that in two bedrock samples, a phyllite and a quartzite, was less than $0.02 \mathrm{ppm}$ in each.

Clifford, Tom N. Tectono-metallogenic units and metallogenic provinces of Africa: Earth and Planetary Sci. Letters, v. 1, no. 6, p. 421-434, 28 references, 1966.

A study of the major mineral deposits of Africa (Rhodesia-Transvaal, West Africa, Tanzania, and Anglo-Kasai) in relation to the structure of the continent reveals two tectono-metallogenic units. Younger orogens consist of zones which have periodically suffered orogenesis and are characterized by major deposits of $\mathrm{Cu}, \mathrm{Pb}, \mathrm{Zn}, \mathrm{Co}, \mathrm{Sn}, \mathrm{W}, \mathrm{Be}$, and $\mathrm{Nb}$-Ta. Older cratons have a record of older orogenesis but have stayed stable throughout younger periods of tectonism and are characterized by important deposits of $\mathrm{Au}$, $\mathrm{Fe}, \mathrm{Cr}$, asbestos, and diamonds. The more localized metallogenic provinces of ore concentration within the two major units are described.

Clifton, H. Edward. Gold distribution in surface sediments on the continental shelf off southern Oregon-A preliminary report: U.S. Geol. Survey Circ. 587, 6 p., 8 references, 1968. 
Ref.

Local gold concentrations ranging from five to almost $150 \mathrm{ppb}$ have been identified in surface sediments of the continental shelf off southern Oregon between Cape Arago and Cape Sebastian. Gold is associated with black sands believed to be relict beach placers, so that its low concentration may indicate higher grade material at depth.

43 Clifton, H. Edward; Hubert, Arthur E.; Phillips, R. Lawrence. Marine sediment sample preparation for analysis for low concentrations of fine detrital gold: U.S. Geol. Survey Circ. 545, 11 p., 16 references, 1967.

Analyses were made by atomic absorption spectrography of 2,000 samples of offshore, beach, marine terrace, and stream sediments from areas along the southern Oregon coast from Brookings to Coos Bay. Concentration of the sediments by sieving and gravimetric and magnetic separations prior to analysis eliminated the effect of particle sparsity from the final results and thus increased the sensitivity of the technique. In almost all marine and beach sands studied, gold occurred in the nonmagnetic fraction smaller than $0.124 \mathrm{~mm}$ and had a specific gravity greater than 3.3, whereas the grain size in gold from stream sediments was slightly higher. Gold rarely exceeded $1 \mathrm{ppm}$ in even the richest black sands studied.

44 Clifton, H. Edward; Hunter, Ralph E.; Swanson, Frederick J.; Phillips, R. Lawrence. Sample size and meaningful gold analysis: U.S. Geol. Survey Prof. Paper 625-C, p. Cl-C17, 20 references, 1969.

A sample of geologic material is of adequate size for gold analysis if it is large enough to insure that the analysis will have a specified degree of precision. It can be shown mathematically that if (1) gold particle mass is uniform, (2) gold particles make up less than 0.1 percent of all the particles, (3) the sample contains at least 1,000 particles of all kinds, (4) analytical errors are absent, and (5) the gold particles are randomly distributed through the deposit being sampled, the precision is determined solely by the number of gold particles in the sample. The precision afforded by 20 particles per sample is deemed sufficient for most purposes. (From authors' abs.)

45 Cloke, Paul L.; Kelly, William C. Solubility of gold under inorganic supergene conditions: Econ. Geology, v. 59, no. 2, p. 259-270, 12 references, 1964.

If an activity of $10^{-5}$ moles per liter is chosen as the lower limit of its geologic solubility, gold dissolves in acid chloride solutions at $\mathrm{pH}$ values more acid than 5.5, oxidation potentials greater than 0.90 volts, and chloride ion activities greater than $10^{-3.2}$ moles per liter, and the auric chloride is the stable dissolved species. Mine waters of ten have the required chloride ion concentration but lack the combination of high acidity and high oxidation potential. This may explain the general immobility of gold in the oxide zone.

46 Cobb, Edward H. Lode gold and silver occurrences in Alaska: U.S. Geol. Survey Mineral Inv. Resource Map MR-32, scale 1:2,500,000, with text, about 270 references, 1962.

Resources map shows location of lode gold deposits in Alaska and indicates those from which production has been recorded.

47 Cobb, Edward H. Placer gold occurrences in Alaska: U.S. Geol. Survey Mineral Inv. Resource Map MR-38, scale 1:2,500,000, with text, about 410 references, 1964. 
Ref.

Resources map shows location of placer gold deposits in Alaska and indicates those from which production has been recorded.

48 Coetzee, F. Distribution and grain-size of gold, uraninite, pyrite and certain other heavy minerals in gold-bearing reefs of the Witwatersrand Basin: Geol. Soc. South Africa Trans., v. 68, p. 61-88, 12 references, 1965.

More than 200 samples of auriferous conglomerate and pyritic quartzite as well as associated footwall and hanging-wall quartzites of the various reefs of the Witwatersrand basin were examined. Mineral constituents of the samples were studied in heavy concentrates and in thin and polished sections of original rock. The generally direct proportions of the gold content to the uraninite, pyrite, and other heavy minerals indicate that they were all deposited together as detrital grains and have a sedimentary origin. Both the gold and heavy minerals are concentrated in the pyrite-rich layers, and no detectable migration of gold from these layers appears to have taken place.

49 Crocket, James H.; Keays, R. R.; Hsieh, S. Precious metal abundances in some carbonaceous and enstatite chondrites: Geochim. et Cosmochim. Acta, v. 31, no. 10, p. 1615-1623, 21 references, 1967.

Analyses by the neutron activation method made for the gold and platinum metals content of nine chondrites gave an average atomic abundance of 0.18 gold for the seven carbonaceous types and 0.19 gold for the two enstatite types, all relative to $10^{8}$ silicon atoms.

50 Curtin, Gary C.; Lakin, Hubert W.; Neuerburg, George J.; Hubert, Arthur E. Utilization of humus-rich forest soil (mull) in geochemical exploration for gold: U.S. Geol. Survey Circ. 562, 11 p., 6 references, 1968.

Distribution of gold in humus-rich forest soil (mull) reflects the known distribution of gold deposits in bedrock in the Empire district, Colorado. Gold from the bedrock is accumulated by pine and aspen trees and is concentrated in the mull by the decay of organic litter from the trees. Anomalies in mull which do not coincide with known gold deposits merit further exploration. The gold anomalies in soil (6- to 12 -inch depth) and in float pebbles and cobbles poorly reflect the known distribution of gold deposits in bedrock beneath the extensive cover of colluvium and glacial drift. The gold content of the mull, humus-rich forest soil ash, was from less than 0.04 to more than $0.60 \mathrm{ppm}$. The gold content of pebbles and cobbles in both glacial drift and colluvium was from less than 0.20 to more than $5.0 \mathrm{ppm}$. (Authors' abs.)

51 Davidson, Claire B. Geochemical prospecting abstracts, January 1961December 1962; U.S. Geol. Survey open-file rept. 955, 255 references, 1967.

General bibliography includes some abstracts on geochemistry of gold.

Davidson, Claire B.; Markward, Ellen L.; Cieslewicz, John. Geochemical prospecting abstracts, July 1957-December 1960: U.S. Geol. Survey open-file rept. 954, 505 references, 1967.

General bibliography includes some abstracts on geochemistry of gold.

53 DeGrazia, A. R. Haskin, L. On the gold contents of rocks: Geochim. et Cosmochim. Acta, v. 28, no. 5, p. 559-564, 10 references, 1964.

Samples of 41 materials were examined for gold content by using the neutron activation method. Characteristic values in parts per billion for the 
Rel.

various rock types were as follows: acid igneous and metamorphic rocks, $2.4 \pm 1.8$; basic igneous and metamorphic rocks, $2.6 \pm 0.6$; Mid-Atlentic Ridge basalts, $10 \pm 3$; carbonates, $2.5 \pm 1.4$; shales, $4.7 \pm 1.6$; sandstones, $6.0 \pm 3.5$; and pelagic clays, $12 \pm 7$. The spread of gold concentrations for the wide variety of samples appears relatively narrow and lies between 0.6 and $44 \mathrm{ppb}$. This seems to indicate a crustal abundance of approximately 2.5 ppb.

54 Denisov, S. V.; Koshman, P. N.; Yugay, T. A. Elementy-primesi v zolote nekotorykh rayonov Priamur'ya [Trace elements in gold from some districts of the Amur region]: Geokhimiya, no. 9, p. 1123-1126, 1966; English translation in Geochemistry Internat., v. 3, no. 5, p. 904-908, 1966.

Two gold-bearing zones in U.S.S.R. are the Glavnyy Priamurskiy in the Amur region and the Primorskiy in the Maritime Territory. The main goldbearing districts are in Glavnyy Priamurskiy and are associated with a geosynclinal region. The others are among normal sedimentary Jurassic and Cretaceous deposits breached by Upper Cretaceous granitic intrusive rocks and by Mesozoic-Cenozoic volcanic rocks. The Galvnyy Priamurskiy gold has a more stable and higher assay than that from the Primorskiy zone, where sources are mixtures of epithermal, mesothermal, and intermediate types. A wide variety of trace elements was present in gold from both areas.

55 Douglas, J. Sholto. Geobotany-A valuable aid in prospecting and mining: Mining Mag., v. 118, no. 2, p. 93, 95, 1968.

A gold deposit related to gold accumulation in tree seeds, branches, and roots occurs at Watson Bar Creek in British Columbia. Five species (unnamed) were sampled. On the strength of the analyses, shafts were sunk and useful bodies of gold-bearing ore were found. Comparative studies of similar species elsewhere might provide an ore guide to other deposits.

Dvornikov, A. G. Tipy oreolov rasseyaniya rtuti v yugo-vostochnoy chasti Donbassa [Types of mercury dispersion aureoles in the southeastern part of the Donets Basin]: Akad. Nauk SSSR Doklady, v. 154 , no. 5, p. 1110-1112, 16 references, 1964; English translation in Acad. Sci. U.S.S.R. Doklady, Earth Sci. Sec., v. 154, nos. 1-6, p. 158-160, 1964.

Mercury dispersion aureoles around ore deposits and tectonic features are characteristic of the rocks and soils in the southeastern Donets basin. Such aureoles may be indicative of lead, zinc, and gold ore deposits. (Author's abs.)

57 Dvornikov, A. G.; Vasilevskaya, A. E.; Shcherbakov, V. P. Nekotoryye osobennosti resprostraneniya oreolov rasseyaniya rtuti $\mathbf{v}$ pochvakh Nagol'nogo kryazha [Mercury dispersion aureoles in the soils of the Nagol'nyi Range]: Geokhimiya, no. 5, p. 478-483, 12 references, 1963; English translation in Geochemistry, no. 5, p. 501-509, 1963.

Mercury halos in the A horizon of soils in the Nagol'nyi Range coincide with a belt of polymetallic and gold deposits and with fault zones, anticline crests, and zones of quartz veins. High mercury concentrations in this soil layer may serve as ore guides to new mineralized zones. 
Ref.

58 Eales, Hugh V. Determining fineness variation characteristics in gold ores by reflectometry: Econ. Geology, v. 63, no. 6, p. 688-691, 7 references, 1968; discussion by E. F. Stumpfl, v. 64, no. 3, p. 341-342, 1969 .

A method of determining fineness of gold by reflectometry is explained and illustrated. In a study of sulfides from Blanket mine, Rhodesia, the fineness of gold from clean arsenopyrite to mixed arsenopyrite and from pyrrhotite to clean pyrrhotite ranged from 907 to 313 , whereas a concentrate with much free gold and a content of $139.7 \mathrm{oz} \mathrm{Au}$ per ton and $13.3 \mathrm{oz}$ Ag per ton gave a fineness of 913. Clear frequency maxima of 900-940 and 780-820 in each sample studied, and of 660-720 in two of larger grain size, suggest three pulses in a single episode of mineralization. Fineness of gold in hypogene ores also seems to be related to associated ore minerals.

59 Elliott, James E.; Wells, John D. Anomalous concentrations of gold, silver, and other metals in the Mill Canyon area, Cortez quadrangle, Eureka and Lander Counties, Nevada: U.S. Geol. Survey Circ. 606, 20 p., 6 references, 1968.

Fissure veins in Jurassic quartz monzonite and a bordering Devonian limestone have produced gold and silver ores for the past 100 years. Anomalous amounts of gold, silver, and related metals have been recorded. The gold content ranges from less than 0.1 to $160 \mathrm{ppm}$ which suggests that a favorable host rock for gold, the Roberts Mountains Limestone, may be found at depth at the mouth of Mill Canyon.

60 Emmons, William H. Gold deposits of the world, with a section on Prospecting: New York, McGraw-Hill Book Co., 562 p., bibliography, 1937.

Reviews worldwide distribution and occurrence of gold deposits.

61 Epshtein, Yu. A. Gneysovyy kupol v Yuzhnom Primor'ye i yego vliyaniye na razmeshcheniye zolotonosnosti [Gneissic dome in southern Primor'ye and its effect on the distribution pattern of gold]: Sovetskaya Geologiya, no. 1, p. 116-118, 6 references, 1968; English translation in Internat. Geology Rev., v. 11, no. 1, p. 135-137, 1969.

A gneissic dome at the intersection of a blind fracture and the northeastern synclinal fold in Permian sediments appears to be related to gold mineralization. The position of mineralization is controlled by the same fracture and fold. Economic gold placers are known in almost every stream valley within the dome and in valleys of streams originating in the dome. There are also gold lodes and "shows" in the dome area, and the estimated gold content per unit area is considered more than 10 times as high as that of the auriferous belt as a whole.

62 Erickson, R. L.; VanSickle, G. H.; Nakagawa, H. M.; McCarthy, J. H., Jr.; Leong, K. W. Gold geochemical anomaly in the Cortez district, Nevada: U.S. Geol. Survey Circ. 534, 9 p., 9 references, 1966.

An area in the Cortez district, Nevada, previously established to be anomalous in arsenic, antimony, and tungsten has been found to be anomalous also in mercury and gold. Samples from narrow quartz veins, calcite veins, and shear zones in partially silicified limestone in the lower plate of the Roberts thrust fault (Cortez window) contain as much as 3.4 ounces gold per ton. The richest samples are from an outcrop, about 100 feet long, surrounded by gravels. Their economic significance is yet to be established. (Authors' abs.) 
Ref.

63 Erikson, Jane E. Geochemical prospecting abstracts, July 1952-December 1954: U.S. Geol. Survey Bull. 1000-G, p. 357-395, 117 references, 1957.

General bibliography includes some abstracts on geochemistry of gold.

64 Fakhri, A. Zonal'nost pervichnykh oreolov zolotorudnogo mestorozhdeniya i migratsionnaya sposobnost' elementov [Zoning of primary dispersion halos over a gold deposit and the migration capacity of the elements]: Moskov. Univ. Vestnik, Ser. 4, Geologiya, no. 5, p. 31-43 8 references, 1965; English abs. in Chem. Abs., v. 64, no. 8, col. 10938, 1966.

Primary dispersion halos, 8-50 $\mathrm{m}$ wide, were found over a gold deposit in Kazakhstan and showed zoning produced by differences in migration capacity of the individual elements. Horizontal zoning from the halo center out was expressed by the series: $\mathrm{Bi}<\mathrm{Pb}<\mathrm{Au}<\mathrm{As}$. Vertical zoning was controlled by position of maximum precipitation of the elements at depths of formation of $150 \mathrm{~m}$ for $\mathrm{Bi}, 175 \mathrm{~m}$ for $\mathrm{Pb}, 205 \mathrm{~m}$ for $\mathrm{As}$, and $285 \mathrm{~m}$ for $\mathrm{Au}$. Correlation indices between pairs of elements, such as $\mathrm{As}-\mathrm{Au}$, $\mathrm{Ag}-\mathrm{Au}, \mathrm{Bi}-\mathrm{Au}, \mathrm{Zn}-\mathrm{Au}, \mathrm{Pb}-\mathrm{Au}$, and $\mathrm{Cu}-\mathrm{Au}$, changed regularly in the vertical section of the ore zone. These indices and this type of halo may serve as exploration guides for evaluating both geochemical anomalies and mineralization at increased depths.

65 Fayzullin, R. M. K probleme promezhutochnykh kollektorov zolota [Problems of intermediate collectors of gold]: Sovetskaya Geologiya, no. 2, p. 129-132, 2 references, 1968; English translation in Internat. Geology Rev., v. 10, no. 12, p. 1383-1385, 1968.

Analyses of auriferous conglomerates in the Kamenskoye gold field, eastern Zabaykal'ye, U.S.S.R., indicate that the conglomerates represent an intermediate collector or interceptor step in the lode-eluvial placeralluvial placer pattern of placer formation. The conglomerates carry gold in free form and in cement (clastogene gold) as well as in ore and rock fragments (ore gold). Climate, nature of relief, and stream erosion influence the amount and form of gold present in conglomerates. Thus in some places the geologic pattern for placer formation should allow for these additional steps: lode-interceptor-alluvial placer; lode eluvial (or eluvial-alluvial) placer-interceptor-alluvial placer; and, rarely, interceptor-alluvial placer.

66 Firsov, L. V. Formatsiya zoloto-kvartsevykh mestorozhdeniy YanoKolymskogo poyasa [Gold-quartz ore deposits of the Yana-Kolyma belt], in Endogennyye rudnyye formatsii Sibiri i Dal'nego Vostoka [Endogene ore formations of Siberia and the Far East]: Moscow, Nauka, p. 132-144, 4 references, 1966; English translation in Internat. Geology Rev., v. 9, no. 12, p. 1544-1552, 1967.

The Yana-Kolyma belt is one of the world's largest metallogenetic structures. Gold placers in the belt have been worked for 30 years but are still important. There are also several hundred gold-quartz ore deposits which are the source of the placer gold and need to be developed as new gold reserves to replace worked-out placers. The textures of vein fillings in the gold-quartz formation are banded, brecciated, brecciform, and platy. The ores belong to the low-sulfide type and are Cretaceous in age. The ore material was transferred by hypogene solution in the colloidal state.

416-169-71-4 
Ref:

67 Fischer, R. P.; Fisher, F. S. Interpreting pan-concentrate analyses of stream sediments in geochemical exploration for gold: U.S. Geol. Survey Circ. 592, 9 p., 1 reference, 1968.

Methods of collecting and processing samples were studied to see if gold is present in moderate-sized areas of the northwest part of the San Juan Mountains, Colo. Samples of pan concentrates were taken from streams which drain "barren" areas where no gold has been reported, slightly mineralized areas where only. a few veins and prospects are known, and wellmineralized areas with many veins and some very productive mines. The concentrates were studied as possible ore guides to sites meriting further exploration.

68 Fitzgerald, A. C.; Graham, R. J.; Gross, W. H.; Rucklidge, J. C. The application and significance of gold-silver ratios at Val d'Or, Quebec: Econ. Geology, v. 62, no. 4, p. 502-516, 8 references, 1967.

In the Lamaque and Sigma ore zones, many gold-quartz veins extend as deep as 4,000 ft. The gold-silver values from 30 years of mint returns from both zones represent very large samples and increase with depth in both mines. The gold-silver ratio obtained from electron probe microanalysis of gold grains from stope samples were about three times higher (18:1) than from conventional analyses $(5.5: 1)$. Both intra-stope variations and increase in gold-silver ratio with depth are caused by the presence of Ag-bearing minerals other than the native alloy or by the absence of Au-bearing minerals. Gold-silver mint return values may be significant around a mine but conclusions of ore genesis based on them are questionable.

69 Fortescue, J. A. C. Background, scope and objectives, Sec. A, in Progress report on biogeochemical research at the Geological Survey of Canada 1963-1966: Canada Geol. Survey Paper 67-23, Pt. 1, p. 1-29, 80 references, 1967.

This review of the history, objectives, and scope of biogeochemical and geobotanical prospecting activities in various parts of the world also includes a little information on gold. The general principles discussed would be applicable for use of the technique in gold exploration.

70 Foster, Robert L. Potential for lode deposits in the Livengood gold placer district, east-central Alaska: U.S. Geol. Survey Circ. 590, 18 p., 10 references, 1968.

The Livengood district contains small bedrock deposits that probably were the source of the placer gold. Some of the stream sediments, especially the Ruth Creek drainage, have anomalously high concentrations of gold, arsenic, mercury, antimony, molybdenum and silver; Ruth Creek has highly acid water. The geological setting and anomalous metal suite are similar to the Carlin-type gold deposits but the significance of these similarities is not yet known. The placer deposits represent a sizable gold resource warranting further economic appraisal.

71 Fouché, K. F.; Smales, A. A. The distribution of gold and rhenium in iron meteorites: Chem. Geology, v. 1, no. 4, p. 329-339, 15 references, 1966.

Neutron activation analysis was used to determine the gold and rhenium content in 70 iron meteorites representative of most structural groups. The meteorites contained from 0.55 to $3.61 \mathrm{ppm}$ gold. The results of the analyses are discussed in relation to the distribution of other trace elements in iron meteorites previously reported. 
Ref.

72 Fouché, K. F.; Smales, A. A. The distribution of trace elements in chondritic meteorites-[Pt.] 2, Antimony, arsenic, gold, palladium, and rhenium: Chem. Geology, v. 2, no. 2, p. 105-134, 55 references, 1967.

Contents of gold and the other elements were obtained in the magnetic and nonmagnetic fractions of eight bronzite, nine hypersthene, and four enstatite chondrites as well as in six carbonaceous chondrites representing all three classes. Results showed that all five elements were predominantly siderophile in chondrites. The average abundance of gold in parts per million was 1.37 in bronzite chondrites, 2.32 in hypersthene chondrites, and 2.21 in enstatite chondrites. In carbonaceous chondrites, the gold range in parts per million was 0.12 to 0.73 .

73 Frondel, Clifford. Stability of colloidal gold under hydrothermal conditions: Econ. Geology, v. 33, no. 1, p. 1-20, about 30 references, 1938.

Colloidal silica protects colloidal gold both against electrolyte and against spontaneous coagulation by increase of temperature. The stability of unprotected and, in particular, protected sols toward electrolyte increases with increasing temperature. Unprotected sols containing no added electrolyte coagulate spontaneously at $150^{\circ}$ to $250^{\circ} \mathrm{C}$., but protected sols are stable at $350^{\circ} \mathrm{C}$. The stability of protected and unprotected negative gold sols toward electrolyte is increased by the addition of $\mathrm{NaOH}$ within a certain limit but is decreased by the addition of $\mathrm{HCl}$. The conditions of transportation and deposition of gold in acid and alkaline hydrothermal solutions are discussed. (From author's abs.)

74 Galkin, M. A. Mineral'nyye assotsiatsii na rtutnykh mestorozhdeniyakh severo-vostochnoy Yakutii [Mineral associations in mercury deposits of northeastern Yakutia]: Akad. Nauk SSSR Doklady, v. 169, no. 2, p. 438-440, 1966; English translation in Acad. Sci. U.S.S.R. Doklady, Earth Sci. Sec., v. 169, nos. 1-6, p. 165-167, 1967.

Four types of mineral association are recognized in mercury deposits, namely gold-antimonite, gold-cinnabar, cinnabar, and cinnabar-realgar; they were separated from each other by tectonic movements. Gold-antimonite deposits are localized in discordant mineralized shatter zones and in conformable lenticular pockets; gold and pyrite and quartz are main ore minerals in shatter zones and antimonite and subordinate gold and pyrite are main ore minerals in lenses. Gold-cinnabar deposits associated with pyrite also occur in discordant and conformable shatter zones. In these first two stages, silicification of wallrock was present and gold was the main constituent ore.

75 Gallagher, David. Albite and gold: Econ. Geology, v. 35, no. 6, p. 698-736, about 166 references, 1940 .

Many gold deposits reported to be genetically related to albite-rich igneous rocks are low in silver and simple sulfides, whereas those related to potash-rich rocks are argentiferous, polymetallic, or abundant in sulfides. The albite-rich type cannot be explained by a one-magma theory of petrogenesis. The granitic and trondhjemitic suites with their respective pegmatites and gold deposits were derived from two distinct magma types. The nature of associated feldspars is significant enough to warrant further study. 
Ref.

76 Garrett, R. G.; Nichol, Ian. Regional geochemical reconnaissance in eastern Sierra Leone: Inst. Mining and Metallurgy Trans., v. 76; Sec. B, Bull. 726, p. B97-B112, 29 references, 1967; discussion, v. 77, Sec. B, Bull. 738, p. B78-B79, 1968; authors' reply, v. 78, Sec. B, Bull. 747, p. B54-B55, 1969.

Distribution of minor elements in stream sediments associated with Precambrian schist belts shows variations of both economic and fundamental significance. Differences in distribution of $\mathrm{As}-\mathrm{Au}, \mathrm{Cr}$, and $\mathrm{Mo}$ may indicate the existence of minor metallogenic and geochemical provinces. Association of As and $\mathrm{Au}$ is such that As may serve as an Au ore guide in almost all the auriferous areas studied in eastern Sierra Leone.

77 Gay, N. C. A review of the geochemical characteristics of gold in ore deposits: Witwatersrand Univ. Econ. Geology Research Unit Inf. Circ. 12, 70 p., 90 references, 1963.

Reviews the ore minerals associated with gold mineralization, the elements in gold ores and host rocks, the mode of gold occurrences in sulfide minerals, the gold-copper ratio in ores, the composition and trace-element content of native gold, and the fineness of gold ores in terms of variations in the goldsilver ratio and its applications. Examples are given from deposits on all the continents but with emphasis on the Witwatersrand deposits of South Africa.

78 Ginzburg, V. L.; Rogover, G. B. Zakonomernosti raspredeleniya tsvetnykh i blagorodnykh metallov $\mathrm{v}$ glavneyshikh rudnykh mineralakh $\mathrm{i}$ silikatakh Noril'skogo mestorozhdeniya [Regularities in the distribution of nonferrous and precious metals in principal ore minerals and silicates of the Noril'sk deposits]: Sovetskaya Geologiya, no. 3, p. 48-60, 1960; English translation in Internat. Geology Rev., v. 3, no. 10, p. 917-926, 1961.

Studies were made of copper, nickel, cobalt, platinum, gold, and rhodium distribution in basic ore-forming sulfide minerals (chalcopyrite and pyrrhotites) and in the silicate parts of the host rocks of the Noril'sk deposit. The cobalt and precious-metal content in the sulfides increased with an increase in nickel content, but the relative contents, estimated for 1 percent $\mathrm{Ni}$, differed in chalcopyrites and pyrrhotites. The former showed a high platinum, palladium, and gold content and the latter, high cobalt and rhodium. The chalcopyrite contained 20 times as much gold as the pyrrhotites.

79 Gmelin, Leopold. Gmelins Handbuch der Anorganischen Chemie, System-Nummer 62, Gold: Weinheim-Bergstrasse, Verlag Chemie, GMBH., p. 125-133, bibliography, 1954.

Reviews the earlier literature on the occurrence of gold in sea sediments and sea water, streams, thermal springs, and in plants and animals.

80 Goleva, Galina Aleksandrovna. Gidrogeokhimicheskiye poiski skrytogo orudeneniya [Hydrogeochemical exploration for buried ore bodies]: Moscow, Izdatel. Nedra, 291 p., 274 references, 1968; English annotations in Internat. Geology Rev., v. 9, no. 11, p. 1511, 1967 (prepublication note) and Bibliography and Index of Geology, Monthly Abs., v. 33 , no. 5 , p. $823,1969$. 
Ref.

Trace-element halos indicate the migration of gold, copper, molybdenum, tungsten, and mercury in ground water. Geochemical studies were made on the ground water and also on streams.

81 Goni, J.; Guillemin, C.; Sarcia, C. Géochimie de l'or exogène-Etude expérimentale de la formation des dispersions colloïdales d'or et de leur stabilité [Geochemistry of exogenic gold-Experimental study of the formation of colloidal dispersions of gold and their stability (with English abs.)]: Mineralium Deposita, v. 1, no. 4, p. 259-268, 18 references, 1967.

The stability of colloidal suspensions of gold, their transport and flocculation have been investigated; in addition, the experimental formation of gold nuggets under natural conditions was studied. The measurements of $\mathrm{pH}$, $\mathrm{Eh}$, and the concentration of ionic gold proved that the possibility of transportation of ionic gold in nature was overestimated. Ionic or even metallic gold may give stable colloidal suspensions. It may be easily flocculated and may give by compaction gold nuggests similar to natural gold nuggets. By diffusion of gold solutions in silica gel, we obtained direct gold films and also some textures frequently present in gold deposits. (Authors' abs.)

82 Goodwin, A. M. Volcanism and gold deposition in the Birch-Uchi Lakes area [Ontario]: Canadian Mining and Metall. Bull. v. 58, no. 635, p. 301-314, 10 references, 1965; Canadian Inst. Mining and Metallurgy Trans., v. 68, p. 94-104, 1965.

Volcanic components are arranged in superimposed sequences or cycles, which show a progression from predominantly mafic effusive rocks below to predominantly felsic extrusive rocks above. Gold occurrences are preferentially distributed in respect to the volcanic succession, 39 of 50 occurrences being in the upper felsic division of the lower volcanic cycle and 40 associated with closely interbanded dacite-rhyolite pyroclastic rocks. A common magmatic derivation for gold and the enclosing volcanic rocks is suggested. The suggested origin of the gold is the classical hydrothermal theory or the direct volcanic theory.

83 Gott, Garland B.; McCarthy, J. Howard, Jr. Distribution of gold, silver, tellurium, and mercury in the Ely mining district, White Pine County, Nevada: U.S. Geol. Survey Circ. 535, 5 p., 12 references, 1966.

Gold, silver, tellurium, and mercury are distributed in zones related to alteration centers, as halos around cores of iron and major copper deposits. Discovery of similar zoning patterns elsewhere may serve as ore guides to deposits of the Ely type. Gold content is sufficiently high (1.5 to $3.0 \mathrm{ppm}$ ) in four local areas of high metal concentration to warrant further exploration.

84 Gott, Garland B.; McCarthy, J. Howard, Jr.; VanSickle, Gordon H.; McHugh, John B. Distribution of gold, tellurium, silver, and mercury in part of the Cripple Creek district, Colorado: U.S. Geol. Survey Circ. 543, 9 p., 13 references, 1967.

Surface sampling of volcanic rocks between gold production veins showed an average content of $0.6 \mathrm{ppm} \mathrm{Au}$. In an area near the Cresson mine, samples 
Ref.

averaged $2.5 \mathrm{ppm}$ Au but ranged in content as high as $9.1 \mathrm{ppm} \mathrm{Au}$. This may indicate the presence of veins with similar content so that further exploration is warranted.

85 Gott, Garland B.; Zablocki, Charles J. Geochemical and geophysical anomalies in the western part of the Sheep Creek Range, Lander County, Nevada: U.S. Geol. Survey Circ. 595, 17 p., 13 references, 1968.

Extensive geochemical anomalies are present along the west side of the Sheep Creek Range in Lander County, Nevada. Anomalous concentrations of zinc, arsenic, mercury, silver, copper, lead, and to some extent gold, molybdenum, and antimony occur in iron-rich material along fracture planes and in quartz veins in Paleozoic formations. (From authors' abs.)

Gross, W. H. Evidence for a modified placer origin for auriferous conglomerates, Canavieiras mine, Jacobina, Brazil: Econ Geology, v. 63, no. 3, p. 271-276, 14 references, 1968.

Quartz-pebble conglomerates and interbedded quartzites of late Precambrian age appear to lie unconformably on acid gneisses and intrusives of early Precambrian age at the Canavieiras mine. Here 28 conglomerate beds were identified, all containing at least a small amount of gold in the matrix between the pebbles and economic concentrations of gold in a foreset system of cross beds. These facts seem to support a placer origin for the gold deposits. The presence of other economic concentrations at the top of conglomerate beds or near intrusive dikes and sills suggests that the original placer gold was redistributed within the conglomerates during periods of folding, metamorphism, and intrusion.

87 Grout, Frank F. On the behavior of cold acid sulphate solutions of copper, silver and gold with alkaline extracts of metallic sulphides: Econ. Geology, v. 8, no. 5, p. 407-433, about 25 references, 1913.

Gold is removed from its acid solutions by several minerals, but it is removed largely in metallic form rather than as sulfides in the secondary enrichment of deposits. Process of enrichment of sulfide ores under weathering conditions can be duplicated in the laboratory. Solution, transportation, and deposition of the gold are involved in secondary concentrations. At shallower levels the reaction involves oxidation and solution, whereas at greater depths, reduction and deposition are involved. Sulfides can be precipitated readily by treatment with dilute alkaline solution followed by the addition of an acid sulfate solution of the metals.

88 Haber, Fritz. Das Gold im Meere [Gold in the ocean]: Zeitsch. Gesell.

Erdkunde Berlin, Ergänzungsheft 3, p. 3-12, 9 references, 1928.

During the cruise of the ship Meteor in the South Atlantic Ocean between Africa and South America, 1,635 sea-water samples from 186 stations were collected. Analyses of these samples for gold content showed an average of $0.004 \mathrm{ppb}$.

.89 Haber, Fritz. Das Gold im Meerwasser [Gold in sea water]: Zeitsch. Angew. Chemie, v. 40, pt. 1, p. 303-314, about 25 references, 1927; English abs. in Chem. Abs., v. 21, no. 11, p. 1787, 1927.

From a review of the literature on gold content in sea water, the author reported the generally accepted abundance as 5 to $10 \mathrm{ppb}$. From his lab- 
Ref.

oratory studies of Atlantic and Pacific Ocean waters he decided that these figures were far too high. Pacific Ocean sea water of. San Francisco Bay contained 0.002 to $0.055 \mathrm{ppb}$ Au with an average of $0.015 \mathrm{ppb}$ off Oakland and 0.005 to $0.031 \mathrm{ppb} \mathrm{Au}$ with an average of $0.010 \mathrm{ppb}$ off Sausalito. Atlantic Ocean water contained 0.001 to $0.044 \mathrm{ppb} \mathrm{Au}$ with an average of $0.008 \mathrm{ppb}$ in the southern part and, from two sets of samples, an average of 0.047 and $0.040 \mathrm{ppb} \mathrm{Au}$ in the northern polar seas. Haber concluded that extraction of gold from sea water would not be profitable.

90 Hagen, J. C. Some aspects of the geochemistry of platinum, palladium, and gold in igneous rocks with special reference to the Bushveld Complex, Transvaal: Cambridge, Massachusetts Inst. Technology, [Ph. D thesis] 300 p., 119 references, June 1954.

Fire assay and spectrographic studies were made of $\mathrm{Au}, \mathrm{Pt}$, and $\mathrm{Pd}$ contents of rocks in the Bushveld Complex and other areas. The results for $\mathrm{Au}$ (in $\mathrm{ppb}$ ) were the following: Bushveld silicic rocks, 92 ; U.S. silicic rocks, 56 ; basalt, 110, diabase, 47; except for dunite pipes, Bushveld peridotite, 67, others, 53; Bushveld gabbro, 87, others, 101 ; Bushveld pyroxenite, 63, U.S. pyroxenite, 27; Bushveld norite, 62; Sudbury norite, 42; Bushveld anorthosite, 60, Essex anorthosite, 26; chondrites, 70(?); igneous rocks, 90(?); and Atlantic sea water, 0.2.

91 Harbaugh, J. W. Geochemical prospecting abstracts through June 1952:

U.S. Geol. Survey Bull. 1000-A, p. 1-50, 151 references, 1953.

General bibliography includes some abstracts on geochemistry of gold.

92 Hausen, Donald M.; Kerr, Paul F. Fine gold occurrence at Carlin, Nevada, Chap. 46, in Ore deposits of the United States; 1933-1967 (GratonSales Volume), [1st ed.]: New York, Am. Inst. Mining, Metall., Petroleum Engineers, Vol. 1, p. 909-940, 37 references, 1968.

Fine colloidal gold is disseminated in leached carbonate strata of Roberts Mountains Formation in the Lynn window of the Roberts Mountains thrust fault. The ore body, generally stratiform, is more or less conformable with altered beds near the top of the formation. The two recognizable systems of mineralization are an earlier base metal-barite assemblage and a later low-temperature epigenetic $\mathrm{Au}-\mathrm{As}-\mathrm{Hg}$-Sb assemblage emplaced near the surface. Gold deposition was accompanied by extensive silicification and argillic alteration of limestone beds, probably indicating late-stage epithermal mineralization. Gold introduction is attributed to late hydrothermal solutions.

93 Hawkes, Herbert E. Principles of geochemical prospecting: U.S. Geol. Survey Bull. 1000-F, p. 225-355, 272 references, 1957.

This general guide to geochemical prospecting includes some information on gold, with emphasis on its distribution in detrital minerals, plants, rocks, and water and on its mobility in a mineralized environment.

94 Hawkes, Herbert E.; Webb, John S. Geochemistry in mineral exploration:

New York, Harper and Row, 415 p., about 450 references, 1962.

(For gold, see p. 20, 163, 365-366.)

Includes good general discussions on geochemical prospecting techniques and some information on the geochemistry of gold. 
Rof:

95 Hawley, Charles C.; Clark, Allen L. Occurrence of gold and other metals in the Upper Chulitna district, Alaska: U.S. Geol. Survey. Circ. 564, 21 p., 4 references, 1968.

Gold and other metals form deposits near Colorado Creek, the Golden Zone in Bryn Mawr Creek, and Long Creek. The first two occurrences are associated with small quartz porphyry stocks and are of vein, disseminated, and breccia-pipe types. Those at Long Creek are clustered around small quartz porphyry plugs and contain less gold than those in the other two sections. Traces of gold are present in Blind Creek fault area. Anomalous amounts of gold were found in many stream sediment samples.

96 Hawley, Charles C.; Clark, Allen L.; Herdrick, M. A.; Clark, Sandra H. B. Results of geological and geochemical investigations in an area northwest of the Chulitna River, Central Alaska Range: U.S. Geol. Survey Circ. 617, 19 p., 6 references, 1969.

Serpentinite intrusive rocks of the area are hosts to small epigenetic polymetallic lode deposits of copper, gold, and silver. Other such deposits are in the interlayered basalt and limestone at Partin and Canyon Creeks and in porphyry near Costello Creek. Anomalous concentrations of gold and other metals are found in stream sediments at Long, Coal, Shotgun, and McCallie Creeks and near lode occurrences. Some of the streams head into

: the basalt-limestone unit, the host rock at Partin and Canyon Creeks, which suggests that other concentrations may be found.

97 Hawley, Charles C.; Martinez, Elizabeth E.; Marinenko, John. Geochemical data on the South ore zone, White Mountain mine and on the gold content of other mercury ores, southwestern Alaska, in Some shorter mineral resource investigations in Alaska: U.S. Geol. Survey Circ. 615, p. 16-20, 1969.

Mercury ores in southwest Alaska generally are free of gold or contain only trace amounts. A gold content of $0.03 \mathrm{ppm}$ was detected in one new sample from the South ore zone of White Mountain mercury mine. One sample from Cinnabar Creek mine contained $0.14 \mathrm{ppm} \mathrm{Au}$, the highest concentration recorded. Anomalous amounts of $\mathrm{Ti}, \mathrm{As}, \mathrm{Sb}, \mathrm{B}, \mathrm{Cr}$, and $\mathrm{Zr}$ are present in fault gouge of South ore zone. Similar composition of fault gouge elsewhere in the region may be a guide to mineralized areas.

98 Helgeson, Harold C.; Garrels, Robert M. Hydrothermal transport and deposition of gold: Econ. Geology, v. 63, no. 6, p. 622-635, 39 references, 1968; discussions by R. W. Boyle, v. 64, no. 1, p. 112-115, 1969 and W. E. Ewers, v. 64, no. 5, p. 575, 1969.

Geologic characteristics of hydrothermal gold ore deposits suggest that gold-quartz veins form from acid solutions containing 0.001 to about 0.05 $\mathrm{ppm} \mathrm{Au}$. The geologic conclusions agree with the thermodynamic calculations of gold's solubility in concentrated sodium chloride solutions in equilibrium with pyrite and quartz at high temperatures, for enough gold can be carried in solution as aurous chloride complexes to explain hydrothermal gold ore precipitation above $175^{\circ} \mathrm{C}$. Cotectic precipitation of gold, pyrite, and quartz accompanies decrease in temperature. Only gold and pyrite are precipitated by an isothermal increase in $\mathrm{pH}$ and (or) a decrease in the oxidation state of the system. (From authors' abs.) 
Ref.

99 Huffman, Claude, Jr.; Mensik, J. D.; Riley, L. B. Determination of gold in geologic materials by solvent extraction and atomic-absorption spectrometry: U.S. Geol. Survey Circ. 544, 6 p., 9 references, 1967.

Gold content is determined by the cyanide atomic-absorption and the fire assay atomic-absorption methods. In the first, gold is leached with a sodium cyanide solution. The monovalent gold is then oxidized to the trivalent state and concentrated by extracting into MIBK (methyl isobutyl ketone) before estimation by atomic absorption. In the second, a goldsilver bead obtained from fire assay is dissolved in nitric and hydrochloric acids. Gold is concentrated by extraction into MIBK before estimation by atomic absorption. By either method, concentrations as low as $50 \mathrm{ppb} \mathrm{Au}$ can be determined in a 15 -gram sample.

100 Hurst, Vernon J.; Crawford, Thomas J.; Sandy, John. Mineral resources of the Central Savannah River area, Vols. 1-2: Washington, D.C., U.S. Econ. Devel. Adm., v. 1, 467 p., 245 references, 1966; v. 2, 231 p., 1966.

The Georgia gold deposits covered in this survey are in Lincoln, McDuffie, Taliaferro, Warren, and Wilkes Counties and occur as veins, saprolite deposits, and placers.

101 Jenne, E. A.; Chao, T. T.; Heppting, L. M. Use of mercurous chloride to recover trace amounts of gold from waters: Econ. Geology, v. 63, no. 4, p. 420-421, 9 references, 1968.

Concentration and recovery of $50-80$ percent of gold in solutions containing as little as $0.05 \mathrm{ppb} \mathrm{Au}$ are made possible by use of a thin mercurous chloride layer on a membrane filter.

102 Jones, Robert S. Gold content of water, plants, and animals: U.S. Geol. Survey Circ. 625, 15 p., 74 references, 1970.

The author reviews the literature from 1927 through early 1969 for analyses of gold content in water, plants, and animals. In sea water, gold content ranges from 0.001 to $44 \mathrm{ppb}$ with an average of $0.05 \mathrm{ppb}$ found by neutron activation analyses. For natural fresh water, gold content ranges from 0.01 to $2.2 \mathrm{ppb}$ with an average of $0.5 \mathrm{ppb}$ in springs, 0.003 to 4.7 $\mathrm{ppb}$ in rivers, and 0.001 to $0.9 \mathrm{ppb}$ in ground waters. For plant ash, the highest gold content found by neutron activation methods seems to be 36 $\mathrm{ppm}$ with an average of $7 \mathrm{ppm}$. The same methods gave a range of 0.0012 to $430 \mathrm{ppb} \mathrm{Au}$ in dry matter in animals. On the basis of scanty analyses, terrestrial plants and animals appear to contain more gold than the marine types.

103 Jones, Robert S. Gold in igneous, sedimentary, and metamorphic rocks: U.S. Geol. Survey Circ. 610, 27 p., 65 references, 1969.

Gold analyses from reports published between 1886 and 1967 were compiled for 50 rock types, of which more than 25 were igneous; about 15 , sedimentary; and the rest, metamorphic. Igneous rocks contained from 0.2 to $73 \mathrm{ppb} \mathrm{Au}$, with an average of $3.0 \mathrm{ppb}$. Averages in parts per billion for individual igneous rocks were: andesite, 5.2 ; basalt, 3.2 ; diorite, 3.5 ; dunite, 8.2 ; gabbro, 5.4 ; granite, 2.8 ; rhyolite, 12 ; syenite, 2.5 ; and trachyte, 6.5 . Sedimentary rocks contained 0.3 to $41 \mathrm{ppb} \mathrm{Au}$, with averages in parts per billion of: overall, 5.0 ; sandstone, 7.5; shale, 3.9 ; and limestone, 3.5. Meta- 
Ref.

morphic rocks contained 0.86 to $22.4 \mathrm{ppb} \mathrm{Au}$, with averages in parts per billion of : overall; 4.3 ; gneiss, 1.8 ; schist, 5.0 ; quartzite, 4.8 ; and marble, 3.1.

Jones, Robert S. Gold in meteorites and in the Earth's crust: U.S. Geol. Survey Circ. 603, 4 p., 28 references, 1968.

The reported gold contents of meteorites range from 0.0003 to $8.74 \mathrm{ppm}$. Gold is siderophilic, and the greatest amounts in meteorites are in the iron phases. Estimates of the gold content of the earth's crust are in the range of 0.001 to $0.006 \mathrm{ppm}$. (Author's abs.).

105 Jones, Robert S.; Fleischer, Michael. Gold in minerals and the composition of native gold: U.S. Geol. Survey Circ. 612, 17 p., 58 references, 1969.

Gold occurs as the native metal and as alloys with silver, copper, nickel, palladium, and platinum. The native elements contain the most gold and the sulfide minerals are second in content. Nonmetallic minerals carry the least gold, and of these, the dark-colored rock-forming minerals contain more than the light-colored ones. One gold telluride-sulfide, nagyagite, and several gold tellurides are known, but no gold selenides have been reported.

Joralemon, Peter. The occurrence of gold at the Getchell mine, Nevada: Econ. Geology, v. 46, no. 3, p. 267-310, 29 references, 1951.

The Getchell veins are lenticular replacement bodies along a fault zone which cuts all the rocks of the area and is dated tentatively as late Tertiary. The more intensely mineralized parts of the deposit, to which gold shoots are limited, form a shallow blanket with roots projecting downward into areas of sparse mineralization. Most of the gold occurs in minute but microscopically visible particles, although some may occur in submicroscopic particles and some may be in solid solution in pyrite and carbon. The Getchell deposit resembles many quicksilver deposits in the area and may be a gradation between common epithermal gold deposits and cinnabar deposits.

107 Karapetyan, A. I. Kharakhter orudeneniya zolota na odom mednomolibdenovom mestorozhdeniy [Character of gold mineralization in a copper-molybdenum deposit]: Akad. Nauk Armyan. SSR Izv., v. 14, no. 4, p. 37-43, 1961; English translation in Internat. Geology Rev., v. 4 , no. 8 , p. $925-928,1962$.

In this Transcaucasian deposit of gold in copper-molybdenum ores, most of the gold came from late stages of a hydrothermal solution and was deposited with $\mathrm{Cu}-\mathrm{As}-\mathrm{Bi}$ and $\mathrm{Pb}-\mathrm{Zn}-\mathrm{Sb}$ minerals. Early finely dispersed gold was precipitated with iron and copper sulfides, and the later gold, in the form of both tellurides and coarse-grained native gold, was deposited after most of the sulfides. Native gold carries no more than 15 to 20 percent of trace elements, including silver, and thus has a high degree of fineness.

108 Kavanagh, Paul M. Have 6,000 years of gold mining exhausted the world's gold reserves?: Pacific Northwest Metals and Minerals Conf., 3d, Portland, Oreg., 1967, Proc., p. 1-10, 35 references, 1967; Canadian Mining and Metall. Bull., v. 61, no. 672, p. 553-557, 1968.

The author reviews the history of gold mining, covering the major producing gold mines and their geology. Their reserve potential is an estimated one billion ounces in the free world at the present price of $\$ 35$ an ounce. The 
Ref.

possible effects of a price increase on the potential gold reserves is discussed, and it is concluded that, although an exact estimate is impossible to make, the source might be largely from Precambrian rocks throughout the world.

109 Kelly, William C.; Cloke, Paul L. The solubility of gold in near-surface environments: Michigan Acad. Sci., Arts, and Letters Papers 1960, v. 46, p. 19-30, 7 references, 1961.

If an activity of $10^{-5}$ moles per liter is chosen as the lower limit of its geologic solubility, gold dissolves in acid chloride solutions at $\mathrm{pH}$ values more acid than 5.5, oxidation potentials greater than 0.90 volts, and chloride ion activities over $10^{-3.2}$ moles per liter, and auric chloride is the stable dissolved species. Mine waters of ten have the required chloride ion concentration but lack the combination of high acidity and high oxidation potential. This may explain the general immobility of gold in the oxide zone. Study of $\mathrm{Fe}$ and $\mathrm{Mn}$ equilibria in the solubility field shows that gold oxidation to the auric state requires reduction of goethite and limonite to ferrous ion and the reduction of manganese dioxide to manganous ion.

110 Kinkel, Arthur R., Jr.; Lesure, Frank G. Residual enrichment and supergene migration of gold, southeastern United States, in Geological Survey research 1968: U.S. Geol. Survey Prof. Paper 600-D, p. D174D178, 2 references, 1968.

Recent studies in North Carolina, South Carolina, and Georgia indicate that near-surface residual and supergene enrichment occurs in addition to normal placer formation. The enrichment appears where there has been removal of soil particles by surface wasting on gentle slopes but not in thick colluvial material or recently farmed land. The appreciable amounts of gold in limonite deposited in many areas by ground water indicate solution and migration of gold in ground waters, especially when oxidizing sulfides are present. Both the enrichment and supergene transport should be factors for consideration in planning a geochemical sampling program.

111 Kogen, V. S. Mineral'nyye assotsiatsii tsentral'no Apsakanskogo rudnogo polya (Stanovoy khrebet) [Mineral associations of the central Apsakanskoye ore field (Stanovoy range)]: Geologiya Rudnykh Mestorozhdeniy, no. 1, p. 58-67, 7 references, 1968; English translation in Internat. Geology Rev., v. 11, no. 8, p. 860-866, 1969.

The auriferous quartz low-sulfide veins were formed during the following mineral association stages: quartz-sericite in association with pyrite, albite, and carbonate (pre-ore stage of beresitization or hydrothermal alteration of acidic rocks); quartz-pyrite (early ore stage); gold-sulfide-polymetallic complex association (late ore stage at the end of which most of the gold was deposited) with galena, gray tetrahedrite ores, and tellurides. Multistage veins or combined early and late mineral associations yield the most gold. Presence of galena and gray copper ores is a mineralogical indicator of richest gold mineralization, while lead and antimony dispersion halos form a geochemical indicator.

112 Komov, I. L. Novyy tip zolotogo orudeneniya $v$ Yeniseyskom kryazhe [New type of gold-ore mineralization in the Yenisey Range]: Sovetskaya Geologiya, no. 4, p. 143-144, 1968; English translation in Internat. Geology Rev., v. 11, no. 3, p. 298-299, 1969. 
Ref.

The area contains hydrothermal ore deposits of several types of which the quartz-vein deposits had been considered most promising. More recent discoveries of gold-sulfide ore shows in metasomatic quartzites occur both as native gold and as fine disseminations in pyrite. Though the quartzites have been worked primarily for tungsten, they are much more abundant than the quartz-gold veins and thus may furnish a new rich source of ore.

113 Koroleva, N. N.; Korolev, V. A.; Ovechkin, V. V. Zoloto-sul'fidnoye [orudeneniye] $\mathrm{v}$ karbonatnykh porodakh-Novyy tip zolotorudnoy mineralizatsii v Sredney Azii [Gold-sulfide mineralization in carbonate rocks-A new type of gold mineralization in Middle Asia]: Geologiya Rudnykh Mestorozhdeniy, v. 8, no. 5, p. 30-44, 11 references, 1966; English rev. in Econ. Geology, v. 64, no. 3, p. 354-355, 1969.

The country rocks are lower Paleozoic schists, Lower Devonian quartz porphyries, and Middle and Upper Devonian carbonate rock series. Pyrite is the main part of the ore deposit and is accompanied by gold tellurides, silver, bismuth, and tetrahedrite. Of the four generations of pyrite, the second makes up 20-90 percent of the ore bodies and has an average gold content of $113.3 \mathrm{~g}$ per ton. Tetrahedrite, next in abundance, contains microscopic inclusions of gold tellurides. Petzite and calaverite form irregular inclusions and veinlets in native gold.

114 Koschmann, Albert H.; Bergendahl, Maximilian H. Gold in the United States exclusive of Alaska and Hawaii: U.S. Geol. Survey Mineral Inv. Resource Map MR-24, scale 1:3,168,000, with text, 310 references, 1962.

Resource map shows locations of principal gold-mining districts in conterminous United States. Only districts which have produced more than 10,000 oz of gold are discussed, and these are classified into the following production groups: 10,000 to $100,000 \mathrm{oz} ; 100,000$ to $1,000,000 \mathrm{oz}$; and more than 1,000,000 oz. The 4.59 districts covered are in the following 20 States: Alabama, Arizona, California, Colorado, Georgia, Idaho, Michigan, Montana, Nevada, New Mexico, North Carolina, Oregon, Pennsylvania, South Carolina, South Dakota, Tennessee, Utah, Virginia, Washington, and Wyoming.

115 Koschmann, Albert H.; Bergendahl, Maximilian H. Principal goldproducing districts of the United States: U.S. Geol. Survey Prof. Paper 610, 283 p., about 590 references, 1968.

Principal gold-producing districts are described for the following 21 States: Alabama, Alaska, Arizona, California, Colorado, Georgia, Idaho, Michigan, Montana, Nevada, New Mexico, North Carolina, Oregon, Pennsylvania, South Carolina, South Dakota, Tennessee, Utah, Virginia, Washington, and Wyoming.

116 Krauskopf, Konrad B. The solubility of gold: Econ. Geology, v. 46, no. 8 , p. 858-870, 16 references, 1951.

Solubility of gold in various solutions as calculated from electrode potential and free-energy data, agrees well with reported experimental results. In acid solutions, gold dissolves as the ion $\mathrm{AuCl}_{4}^{-}$, of which the formation requires that the solution contain excess $\mathrm{Cl}^{-}$, and contain or be in contact with a fairly strong oxidizing agent. Naturally-occurring and effective oxidizing agents are $\mathrm{MnO}_{2}, \mathrm{O}_{2}, \mathrm{Fe}^{+++}$, and $\mathrm{Cu}^{++} . \mathrm{H}^{+}$and $\mathrm{SO}_{4}^{--}$are not 
Ref.

strong enough agents to affect gold at ordinary temperatures. Although the effect of temperature on solubility cannot be predicted from available thermodynamic data, experiments show that gold solubility increases with rising temperature in both acid and alkaline solutions.

117 Kreyter, V. M.; Aristov, V. V.; Volynskii, I. S.; Krestovnikov, A. B.; Kuvichinskiy, V. V. Povedenie zolota v zone okisleniya zoloto-sulfidnykh mestorozhdenii [The behavior of gold in the zone of oxidation of auriferous sulfide deposits]: Moscow, Gosgeoltekhizdat, 268 p., bibliography, 1959; English rev. by O. Zvyagintsev in Geochemistry, no. 6, p. 683-685, 1959, and by C. F. Davidson in Econ. Geology, v. 55 , no. 8, p. 1761, 1960 .

The book is a study of the distribution of gold in primary and supergene zones of sulfide ore deposits in the Maikain ore field, at Dzhusaly in Kazakhstan, and at Blyava and Novy Sibai in the southern Urals, U.S.S.R. Reviewed are the current theories on hypogene and supergene gold, the formation of secondary auriferous zones, the work done on solubility of gold, the conditions for solution and migration of gold in the oxidation zone, and the problems in the mineragraphic study of gold ores.

118 Lakin, Hubert W.; Nakagawa, Harry M. A spectrophotometric method for the determination of traces of gold in geologic materials in Geological Survey research 1965: U.S. Geol. Survey Prof. Paper 525-C, p. C168C171, 11 references, 1965.

Gold in geologic material such as soil, gossan, and silicified limestone is dissolved with sodium bromate and hydrobromic acid and extracted from dilute hydrobromic acid with ethyl ether. On evaporation of the ether, the aqueous solution of the residue is extracted with 4,4'-bis (dimethylamino) thiobenzophenone, or TMK (Thio-Michler's ketone), in isoamyl alcohol. The absorbance of the red gold-TMK complex is proportional to the amount of gold present. As little as $20 \mathrm{ppb}$ gold can be determined. Thallium in large amounts interferes with the determination. (From Authors' abs.)

119 Law, Stephen L.; Green, Thomas E. Analysis of large samples of low grade gold ores by methyl isobutyl ketone extraction and atomic absorption: U.S. Bur. Mines Heavy Metals Program Tech. Prog. Rept. 7, 7 p., 4 references, 1968.

A method for determining small quantities of gold in large splits (500 grams) from field samples of low-grade ores is described. It is based on the dissolution of the gold in aqua regia, extraction of the gold into MIBK (methyl isobutyl ketone) in the presence of the insoluble residue, and determination of the gold in the MIBK phase by atomic absorption. The method is especially useful for samples from which representative small splits cannot be obtained. (Authors' abs.)

120 Legedza, V. Ya. O roli diageneza $\mathrm{v}$ kontsentratsii zolota $\mathrm{v}$ sul'fidakh nekotorykh osadochnykh porod [Role of diagenesis in the accumulation of gold in sulfides of certain sedimentary rocks]: Akad. Nauk SSSR Doklady, v. 172, no. 5, p. 1177-1179, 20 references, 1967; English translation in Acad. Sci. U.S.S.R. Doklady, Earth Sci. Sec., v. 172, nos. 1-6, p. 206-208, 1967. 
Ref.

Two current views on behavior of gold under supergene conditions are: (1) gold from bedrock deposits and igneous rocks is continuously being disseminated in sedimentary rocks as a result of erosion, and (2) gold can become concentrated in certain types of sedimentary rocks, mainly silty and clayey deposits. In a.study of the sulfides, sandstones, and other sedimentary deposits of the Russian Platform in regard to the relative concentration of gold in sulfides and enclosing rocks, the author concluded that gold becomes concentrated in the sulfides in rocks while the rocks themselves are "cleaned" of gold. Thiosulfate apparently acts as a carrier for both gold and sulfur in sea water and in mud suspensions in sediments to form the diagenetic auriferous pyrite on the Russian Platform.

121 Lenher, Victor. The transportation and deposition of gold in nature: Econ. Geology, v. 7, no. 8, p. 744-750, 15 references, 1912.

The author: reviews the various studies showing that gold is soluble in alkaline sulfides, from which, however, it is not precipitated by pyrite or metallic iron. Such gold-bearing alkaline sulfide solutions can pass through pyrite beds and perhaps enrich themselves by dissolving some gold from the pyrite without losing their own gold content. Precipitation of gold can occur when such a solution meets an acid in a reduced zone or reaches a zone of oxidation.

122 Lincoln, Francis C. Certain natural associations of gold: Econ. Geology, v. 6, no. 3, p. 247-302, about 125 references, 1911.

Studies were made on associations of gold with igneous rocks, subcrustal waters and veins, surface waters and salts, organisms and organic rocks, sedimentary rocks, metamorphic rocks, gold minerals, and minerals in rocks and veins. Gold content was found to average, in milligrams per metric ton, about 62 in igneous rocks, 15 in sedimentary rocks, and 28 in sea water. Gold has been found to be associated with more than 173 mineral species, but only a limited number, including pyrite and galenite, quartz, and minerals containing $\mathrm{As}, \mathrm{Bi}, \mathrm{Se}$, or $\mathrm{Te}$, are apt to carry intergrown or disseminated gold.

Lodder, Willem. Gold-alunite deposits and zonal wall-rock alteration near Rodalquilar, SE Spain: Amsterdam Univ. Geol. Inst. Mededel. 318, 93 p., 117 references, 1966.

The gold deposits near Rodalquilar, Spain, are in the Neogene volcanic ranges of Cabo de Gata. Gold-alunite veins are limited to a complex of strongly altered rocks, most of which are considered ignimbritic in origin. A penecontemporaneous syngenetic origin of the gold ores and the ignimbrites is suggested by the absence of gold veins in underlying rhyodacite and overlying rock units, the wedging out of gold veins towards the rhyodacite, and the concentration of gold deposits below several levels which probably indicates the upper surface of several ashflows. Besides the alunite-quartz zone carrying the gold, other alteration zones are dickite-(pyrophyllite), kaolinite-illite, mixed layer illite-smectite, mixed layer smectite-chlorite, and mixed layer chlorite-vermiculite zones.

124 Lovering, T. G.; Lakin, H. W.; Hubert, A. E. Concentration and minor element association of gold in ore-related jasperoid samples in Geological Survey research 1968: U.S. Geol. Survey Prof. Paper 600-B, p. B112-B114, 7 references, 1968. 
Ref.

Sixty-eight samples of jasperoid associated with base- and precious-metal ore deposits in 25 U.S. western mining districts in Arizona, Colorado, Nevada, New Mexico, South Dakota, and Utah were analyzed for gold by atomic-absorption spectrophotometry, a method capable of detecting concentrations as low as $0.04 \mathrm{ppm}$. The gold content of these samples ranged from less than 0.04 to $32 \mathrm{ppm}$, with a median content of $0.2 \mathrm{ppm}$. A statistical comparison of the gold concentrations in these samples with the corresponding concentrations of 16 minor elements indicates that gold is significantly associated with tellurium, mercury, tin, arsenic, and silver. (From authors' abs.)

125 Luttrell, Gwendolyn W. Base- and precious-metal and related ore deposits of Virginia: Virginia Div. Mineral Resources, Mineral Resources Rept. 7, 167 p., 88 references, 1966.

A summary is given of early history and development of 496 gold and other mines and prospects in the State based on source material dating back to 1837. First gold production took place in 1829 .

126 McCarthy, J. H., Jr.; Learned, R. E.; Botbol, J. M.; Lovering, T. G.; Watterson, J. R.; Turner, R. L. Gold-bearing jasperoid in the Drum Mountains, Juab and Millard Counties, Utah: U.S. Geol. Survey Circ. 623, 4 p., 7 references, 1969.

Geochemical studies and sampling showed anomalous gold concentrations in jasperoid outcrops. One sample contained $100 \mathrm{ppm} \mathrm{Au}$ and 20 samples from an outcrop 50 by $200 \mathrm{ft}$ averaged $10 \mathrm{ppm} \mathrm{Au}$.

127 McCarthy, J. H., Jr.; Vaughn, W. W.; Learned, :R. E.; Meuschke, J. L. Mercury in soil gas and air-A potential tool in mineral exploration: U.S. Geol. Survey Circ. 609, 16 p., 7 references, 1969.

Mercury content in soil gas and the atmosphere was measured in various mining districts to see if it was higher over ore deposits than over barren ground. At Cortez, Nev., anomalous amounts of mercury in soil gas at the surface corresponded to the position of gold deposits, which often were covered by as much as 100 feet of gravel. Mercury content in soil over the same deposits did not reflect gold distribution as well as that in the soil gas.

128 McCauley, Camilla K.; Butler, J. Robert. Gold resources of South Carolina: South Carolina Div. Geology Bull. 32, 74 p., 35 references, 1966.

The gold resources of the State have been produced from low-grade siliceous replacement deposits, from quartz veins less than $10 \mathrm{ft}$ thick, and from placer deposits of stream gravel or other surficial material. Most of the deposits are in Lancaster, McCormick, Chesterfield, and York Counties, although occurrences are also present in 11 other counties.

129 Machairas, Georges. Dissolution et recristallisation de l'or primaire pendant l'oxydo-réduction des sulfures aurifères [Solution and recrystallization of primary gold during oxydo-reduction of gold bearing sulfides (with English abs.)]: [France] Bur. Recherches Géol. et Minières Bull. 5, p. 111-121, 1967.

During natural oxidation-reduction of auriferous pyrite, the primary native gold disseminated in the pyrite is dissolved and then recrystallized 
Ref.

into cubic crystals with goethite. This precipitated secondary gold is less argentiferous than the primary xenomorphic gold remaining in the residue of the nonoxidized pyrite. Experimental studies indicate that the process takes place in three phases: oxidation of pyrite causes gold to be dissolved; reduction causes $\mathrm{FeSO}_{4}$ to recrystallize the gold; and local hydrolysis precipitates the iron oxide around the newly formed gold crystals. Meteoric alteration in the oxidation zone is believed to play an important role in modifying primary gold deposits.

130 Machairas, Georges. Mise en évidence de différentes catégories d'or exogène par l'étude du mode de répartition de l'argent-Ráflexions sur le cycle de l'or exogène [Evidence of different categories of exogenic gold by study of the mode of distribution of silver-Reflections on the cycle of exogenic gold (with English abs.) ] : Soc. Française Minéralogie et Cristallographie Bull., v. 90, no. 3, p. 387-393, 2 references, 1967.

Distribution of silver in primary exogenic gold which was precipitated as nuggets in the oxidation zone shows that recrystallization of the gold occurred in several forms, namely, as successive argentiferous crusts of gold in a. ferruginous matrix, as argentiferous gold with an aggregate structure, and as. idiomorphic and virtually silver-free gold crystals forming cubes, cubooctahedrons, and octahedrons. The dissolving and recrystallization of gold appear to be linked with the oxidation of auriferous sulfides such as pyrite.

131 Mackay, Robert A. The purity of native gold as a criterion in secondary enrichment: Econ. Geology, v. 39, no. 1, p. 56-68, 1 reference, 1944.

Emmons believed that, at times, some secondary gold may be of greater fineness than primary gold within the same ore body whereas Mackay suggests that divergence in purity and its relation to gold particle size in certain types of ore bodies may indicate the zone of the ore body and the approximate degree of secondary enrichment. When coarse gold was separated from fine gold by crushing or by amalgamation with fine gold followed by cyanidation, the coarse or amalgamated fraction had a higher fineness of gold than the smaller particles. The divergence of fineness was proportional to the degree of secondary enrichment. Materials from Nigeria and Tanzania (formerly Tanganyika and Zanzibar) were used.

132 MacKevett, E. M., Jr.; Smith, James G. Distribution of gold, copper, and some other metals in the McCarthy B-4 and B-5 quadrangles, Alaska: U.S. Geol. Survey Circ. 604, 25 p., 6 references, 1968.

The highest concentration of gold found in the area was $66.0 \mathrm{ppm}$ in a channel sample from a prospect north of Crumb Gulch. A chip sample from the Taylor prospect contained $15.4 \mathrm{ppm} \mathrm{Au;} \mathrm{a} \mathrm{small} \mathrm{channel} \mathrm{sample} \mathrm{across} \mathrm{a}$ vein in the Porphyry Mountain area contained $11 \mathrm{ppm} \mathrm{Au}$. In general, the range of gold content in rocks, altered zones, and lodes ranged from 0.01 to $6.8 \mathrm{ppm}$ but generally was less than 0.3 . In stream sediments, gold content in many samples was detectable but not determinable, but also reached a maximum of $1.5 \mathrm{ppm}$ in others, one anomalous sample containing $9.6 \mathrm{ppm}$.

133 McKinstry, Hugh E.; Ohle, Ernest L., Jr. Ribbon structure in gold-quartz veins: Econ. Geology, v. 44, no. 2, p. 87-109; about 45 references, 1949; discussion by E. Y. Dougherty, v. 45, no. 2, p. 177-179, 1950. 
Ref.

Laminated banding in mesothermal and hypothermal gold-quartz veins is formed by interlayering of quartz with slabs or films of country rock. If layers are relatively thick, 1 millimeter to several centimeters, and are formed of country rock, the aggregate is called book structure. When layers are thin films or septa and lack the texture or appearance of country rock, ribbon structure is formed. The origin of the book type has been ascribed to accretion and to replacement, that of the ribbon type, to post-quartz shearing or accretion, or to replacement. From field and laboratory studies the authors decided that the laminated structures are caused by replacement, which not only can produce both types but also can do so in a continuous operation.

134 MacLaren, James M. Gold-Its geological occurrence and geographical distribution: London, Mining Jour., 687 p., footnote references, 1908. (See p. 13-26 and 59-64.)

Reviews the geology and distribution of gold throughout the world.

McLaughlin, D. H.; Wise, E. M. Sources and recovery of gold, Chap. 1, in Wise, E. M., ed., Gold-Recovery, properties, and applications: Princeton, N. J., D. VanNostrand Co., Inc., p. 1-24, 42 references, 1964.

Reviews gold occurrences, types of deposits, and properties.

136 Mantei, Erwin J.; Brownlow, Arthur H. Variation in gold content of minerals of the Marysville quartz diorite stock, Montana: Geochim. et Cosmochim. Acta, v. 31, no. 2, p. 225-235, 14 references, 1967.

The gold content of mineral samples from the Marysville quartz diorite stock had ranges of $0.002-0.924 \mathrm{ppm}$ in biotite, $0.003-0.823 \mathrm{ppm}$ in hornblende, $0.003-0.329 \mathrm{ppm}$ in magnetite, and $0.006-0.176 \mathrm{ppm}$ in quartzfeldspar samples. Lowest values occur at the center of the stock and high ones near the edge; highest values are found near gold mines along the periphery of the stock. Because it did not form bonds in crystallizing minerals, gold was concentrated in residual fluids of the magma and finally deposited in quartz veins at the edge of the stock. It was probably entrapped as unchanged gold atoms in the minerals, the amount present being determined by the mineral structure and the gold concentration in the magma at the time of mineral crystallization.

137 Markham, N. L. Synthetic and natural phases in the system Au-Ag-Te (in two parts): Econ. Geology, v. 55, no. 6, p. 1148-1178, 1960; v. 55, no. 7 , p. 1460-1477, 48 references, 1960 ; discussion by P. L. Cloke, v. 58 , no. 7, p. $1163-1166,1963$, and by Ulrich Petersen, v. 59, no. 7, p. 1390-1394, 1964.

From results of a study of the subsolidus phase relationships of $\mathrm{Au}-\mathrm{Ag}-\mathrm{Te}$, an isothermal section at $300^{\circ} \mathrm{C}$ was drawn showing compatible phases of solid solution. All natural Au-Ag-Te minerals except krennerite and montbrayite have been synthesized. Krennerite seems to be the lowtemperature, low-pressure polymorph of $\mathrm{AuTe}_{2}$, whereas calaverite develops under higher temperatures and pressures. Comparison of the mineral assemblages in tellurides of Western Australia and the Fiji Islands with those obtained experimentally indicates good agreement between the two sets of data. 
Ref:

138. Markward, Ellen L. . Geochemical prospecting abstracts, January 1955June 1957: U.S. Geol. Survey Bull. 1098-B, p. 57-160, 268 references, 1961.

General bibliography contains some abstracts on geochemistry of gold.

139 Masson, Donald L. Plants for geobotanical prospecting-Indicator and accumulator plants used for sampling for geochemical prospecting: Washington State Inst. Technology Circ. 1, 9 p., 1962.

Includes some information on gold indicator plants.

140 Mazzucchelli, R. H.; James, C. H. Arsenic as a guide to gold mineralization in laterite-covered areas of Western Australia: Inst. Mining and Metallurgy Trans., v. 75, Sec. B, Bull. 720, p. B286-B294, 18 references, 1966; discussion, v. 75, Sec. B, Bull. 726, p. B127-B129, 1967; reply by authors, v. 76, Sec. B, Bull. 732, p. B218, 1967.

In Western Australia, geochemical studies of arsenic distribution in laterites demonstrated that the presence of underlying arsenic-gold deposits may be indicated by detection of anomalous arsenic patterns in the laterites. In some cases the arsenic was concentrated in the ferruginous coarser fragments of the lateritic soil, and analysis of the material seems to define broad patterns which may be useful in the reconnaissance stage of prospecting.

141 Merwin, Roland W. Gold resources in the Tertiary gravels of California: U.S. Bur. Mines Heavy Metals Program Tech. Prog. Rept. 3, 14 p., 13 references, 1968.

Preliminary studies of U.S. gold deposits offering a large tonnage potential indicate that the Tertiary gravels of California contain one of the largest known reserves. Their grade is such that a breakthrough in mining or metallurgy could stimulate the resumption of work on these deposits, which ceased production because of hydraulic mining problems in the 1800 's. Remaining gravel reserves are estimated to total 3-4 billion cu yds with an average grade of 25 cents per cu yd. Zones in the lower sections of gravels are estimated to contain 600 to 800 million cu yds with an average value of $\$ 1.00$ per cu yd.

142 Miller, Thomas P.; Ferrians, Oscar J., Jr. Suggested areas for prospecting in the central Koyukuk River region, Alaska: U.S. Geol. Survey Circ. 570, 12 p., 12 references, 1968.

Anomalous amounts of gold were found in some stream-sediment samples and in rock samples from mineralized outcrops at the Indian Mountain, Purcell Mountain, and Zane Hills areas. Mineralization is related to the Upper Cretaceous granitic plutons, which have intruded possibly Upper Jurassic to Lower Cretaceous volcanic rocks ranging in type from quartz latite to andesite. Gold content in rock samples ranged from 0.04 to $6 \mathrm{ppm}$ in the Indian Mountain area, from 0.05 to $2.4 \mathrm{ppm}$ in the Zane Hills area, and from 0.02 to $0.3 \mathrm{ppm}$ in the Hawk River locality of the Purcell Mountain area.

143 Moore, George W.; Silver, Eli A. Gold distribution on the sea floor off Klamath Mountains, California: U.S. Geol. Survey Circ. 605, 9 p., 5 references, 1968 . 
Ref.

Gold anomalies in the continental shelf sediments developed during the Holocene rise in sea level when encroaching waves attacked and reworked gold-bearing Cenozoic sediments derived. originally from the Klamath Mountains deposits. The gold content was $0.1 \mathrm{ppb}$ for the background and more than $10 \mathrm{ppb}$ to $390 \mathrm{ppb}$ for the anomalies.

144 Moore, Lyman. Gold resources of the Mother Lode belt, El Dorado, Amador, Calaveras, Tuolumne, and Mariposa Counties, California: U.S. Bur. Mines Heavy Metals Program Tech. Prog. Rept. 5, 22 p., 13 references, 1968.

The Mother Lode belt, which has produced 13.5 million ounces gold from lodes and twice as much from placers, is considered a source of additional gold made available by improved mining technology. Estimates of gold content in 22 properties with extensive low-grade mineralization are thought to be 16.0 million tons of measured ore averaging 0.8 oz Au per ton for four properties and 27.0 million tons averaging $0.075 \mathrm{oz} A \mathrm{Au}$ per ton for eight properties. Assuming that other low grade ore will be available from known mineralized areas, a total of 148 million tons averaging $\mathbf{0 . 0 5 5}$ oz $\mathrm{Au}$ per ton is inferred for the 22 properties. Similar deposits may be present in other unexamined properties.

145 Murdoch, Joseph; Webb, Robert Wallace. Minerals of CaliforniaCentennial Volume (1866-1966) with sections by Ian Campbell and Eleanor M. Learned: California Div. Mines and Geology Bull. 189, 559 p., references, p. 402-515, 1966.

The gold deposits in 31 counties of the State include both lode and placer deposits. Leading lode-gold producers were Amador, Calaveras, El Dorado, Kern, Mariposa, Nevada, Shasta, Sierra, Siskiyou, Trinity, and Tuolumne Counties. Leading placer-gold producers were Butte, Merced, Placer, Sacramento, Stanislaus, and Yuba Counties.

146 Narayanaswami, S. Geochemical prospecting for gold-bearing lodes in the Kolar gold fields, India, in Symposium de exploracion geoquimica, Vol. 3: Mexico, D. F., Internat. Geol. Cong., 20th, 1956, p. 541-553, 4 references, 1960.

The gold-bearing lodes occur in regionally metamorphosed mafic volcanic rocks of Precambrian age. The main Champion lode is a quartz vein with native gold and minor tourmaline, scheelite, magnetite, ilmenite, galena, pyrrhotite, and arsenopyrite. Three western lodes in the Nundydroog mine are mineralogically similar to the Champion lode but much richer in sulfides, pyrrhotite, arsenopyrite, pyrite, chalcopyrite, and sphalerite. Three experimental geochemical soil sample lines spaced across the strike of the projected outcrop zone of the sulfide lodes and over underground workings of the Nundydroog mine showed high arsenic anomalies over the three western sulfide lodes.

147 Nichol, Ian; James, L. D.; Viewing, K. A. Regional geochemical reconnaissance in Sierra Leone: Inst. Mining and Metallurgy Trans., v. 75, Sec. B, Bull. 712, p. B146-B161, 30 references, 1966; discussion, v. 76, Sec. B, Bull. 723, p. B69-B72, 1967; Authors' reply, v. 78, Sec. B, Bull. 747, p. B52-B54, 1969. 
Ref.

Geochemical prospecting in the Sula Mountains and Kangari Hills area was based on analyses of stream sediments from a mineralized Precambrian schist belt. The latter has widespread distribution of alluvial gold, which has rarely been traced to its source, and also arsenic-gold and molybdenum mineralization. Arsenic anomalies were present around known primary and alluvial gold deposits.

148 Paley, L. Z.; Murovtsev, A. V.; Borozenets, N. I. K geokhimii zolota v Sultanuizdage [The geochemistry of gold in Sultanuizdag]: Uzbek. Geol. Zhur., v. 11, no. 6, p. 50-55, 7 references 1967; English translation in Geochemistry Internat., v. 4, no 6, p. 1197-1201, 1967.

Gold contents (determined by neutron-activation analysis) of rocks and minerals in the vicinity of the Sultanuizdag auriferous veins are extremely variable $(0.0002$ to $0.4 \mathrm{ppm})$ but can be grossly correlated with degree of alteration. Material balance calculations for some samples indicate that only 30 percent of the total gold in the rock is of primary origin, that is, the bulk of the gold was introduced during postmagmatic alteration processes (sericitization, albitization, silicification, and so forth).

149 Parès, Yvette; Martinet, Raoul. Intervention des bactéries dans le cycle de l'or-Etude biologique du phénomène [Intervention of bacteria in the gold cycle-Biological study of the phenomenon]: [France] Bur. Recherches Géol. et Minières Bull. 3, p. 1-29, 90 references, 1964; English abstract in Chem. Abs., v. 64, no. 13, col. 19240. 1966.

Lateritic ores of Ity, Ivory Coast, contain as much as $18.3 \mathrm{ppm}$ of finely dispersed gold. Studies were made on ore samples to discover whether bacterial action might have helped in the dissolution of the gold. Bacteria were found to have some influence in gold solubilization and reprecipitation. Results of many of the experiments showed initial solubilization of gold to concentrations of $6 \mathrm{mg}$ per liter, followed by slow reprecipitation of the dissolved gold.

150 Peshchevitskiy, B. I.; Anoshin, G. N.; Yerenburg, A. M. O khimicheskikh formakh zolota $\mathrm{v}$ morskoy vode [Chemical forms of gold in sea water]: Akad. Nauk SSSR Doklady, v. 162, no. 4, p. 915-917, 13 references, 1965; English translation in Acad. Sci. USSR Doklady, Earth Sci. Sec., v. 162, nos. 1-6, p. 205-207, 1965.

On the basis of a recalculation of the redox potential of sea water as 0.74 volt, the chemical forms of occurrence of gold in sea water have been recalculated and are tabulated in terms of standard potentials of complex gold compounds. All the equilibrium concentrations were similiarly calculated. Gold is present in sea water chiefly as the complex anion $\mathbf{A u C l}_{2}$ - . (Authors' abs.)

151 Peterson, Donald W.; Yeend, Warren E.; Oliver, Howard M.; Mattick, Robert E. Tertiary gold-bearing channel gravel in northern Nevada County, California: U.S. Geol. Survey Circ. 566, 22 p., 26 references, 1968.

A huge Tertiary gravel-filled channel in the area between the South and Middle Yuba Rivers was the site of very productive hydraulic gold mines in the 1800 's. The highest gold values were in the lower parts of the deposits, especially in the so-called blue gravel. A two-mile stretch of the 
Ref.

channel near North Columbia at depths of 100 to $400 \mathrm{ft}$ is thought to contain more than half a million ounces of gold dispersed through about 22 million cu yds of gravel of a grade averaging 81 cents per cu yd. The entire area and others like it may be promising potential gold sources if the hydraulic mining problems can be overcome.

152 Pings, W. B. Bacterial leaching: Colorado School Mines Mineral Industries Bull., v. 11, no. 3, p. 1-19, 82 references, 1968.

Bacterial leaching or biological mining has been used to recover metals from waste dumps or in situ in mines. French workers found that Agrobacterium tumefaciens solubilized gold in amounts as much as $1.5 \mathrm{mg}$ per liter. Autotrophic nitrous and nitric bacteria were capable of solubilizing gold but had much weaker activity than the heterotrophic type.

153 Polikarpochkin, V. V.; Kitayev, N. A.; Sarapulova, V. N. Stroyeniye i vertikal'naya zonal'nost' pervichnykh oreolov rasseyaniya Baleyskogo zolotorudnogo polya [Structure and vertical zonation of the primary dispersion aureoles at the Baley gold deposits: Geokhimiya, no. 8, p. 1024-1037, 7 references, 1965; English translation in Geochemistry Internat., v. 2, no. 4, p. 741-753, 1965.

The Baley epithermal gold-quartz vein deposits are in a structural basin covered by a thick blanket of unconsolidated post-ore sediments. Anomalies in $\mathrm{Au}, \mathrm{Ag}, \mathrm{Sb}, \mathrm{Cu}, \mathrm{Pb}$, and $\mathrm{Zn}$ were mapped by spectrographic analysis of samples from underground workings and drill-holes. Well-defined halos extend up to $300 \mathrm{ft}$ above the ore zone and expand upward from widths of $30 \mathrm{ft}$ to several hundred meters with definite vertical zonation, the $\mathrm{Au}-\mathrm{Ag}$ zone being deepest with the As-Sb zone above it and the copper zone on top. Careful study of many similar structural basins in Siberia and elsewhere may reveal new gold deposits.

154 Razin, L. V.; Rozhkov, I. S. Geokhimiya zolota v kore vyvetrivaniya i biosfere zolotorudnykh mestorozhdeniy Kuranakhskogo [Geochemistry of gold in the weathered crust and biosphere of gold deposits of the Kuranakh týpe]: Moscow, Nauka, 253 p., 87 references, 1966; English rev. in Geochemistry Internat., v. 4, no. 4, p. 830, 1967, and in Internat. Geology Rev., v. 10, no. 6, p. 730-731, 1968.

Kuranakh ores are auriferous sandy-clay fillings in old karst cavities in the Aldanian anteclise, that is, mostly blind ore bodies in the taiga-covered difficult terrains of the Aldan highland, southern Yakutia. Studies were made on gold content in soils, waters, vegetation, and fauna of the area. About 63 percent of all plants analyzed, which consisted of 497 samples from 21 families and 79 species, accumulated gold. Content in trees and shrubs decreased with age. Highest content in plant ash was $1.96 \times 10^{-3}$ percent. The best indicator plants were raspberry, rosemary, dog rose, cedar, Lilicea, mosses, and fungi.

155 Richter, Donald H.; Matson, Neal A., Jr. Distribution of gold and some base metals in the Slana area, Eastern Alaska Range, Alaska: U.S. Geol. Survey Circ. 593, 20 p., 5 references, 1968.

Anomalous concentrations of gold and copper are associated with dioritequartz diorite intrusive rocks as indicated in stream sediments carrying from less than 0.02 to $7 \mathrm{ppm} \mathrm{Au}$ and random samples of dioritic rocks, 
Ref:

from 0.02 to $0.3 \mathrm{ppm} \mathrm{Au}$. Placer gold deposits may be present in streams draining the principal areas anomalous in gold content, and bedrock sources of the anomaly should be evaluated as possible low-grade disseminated gold deposits.

156 Rickard, Thomas A. The formation of bonanzas in the upper portions of gold-veins: Am. Inst. Mining and Metall. Engineers Trans., v. 31, p. 198-220, about 15 references, 1902 .

Enrichment of gold-bearing quartz lode veins associated with pyrite to form gold bonanzas near the surface can occur either by a method of natural concentration or by deposition of additional gold through secondary reactions. Weathering may cause the concentration by removal of base and more soluble constituents of the vein, thus making the same volume of gold ore richer per ton. Secondary enrichment by descending surface waters may also increase the gold content. Rickard considers all ore deposits, regardless of size, to be secondary because the ore to be mined is only the last stage of a series of solution-precipitations through which the ore has passed in a constant shifting caused by underground water circulation.

157 Rickard, Thomas A. The geologic distribution of gold: Eng. and Mining Jour., v. 119, no. 12, p. 486-487, 4 references, 1925.

Suggests that the origin of gold and silver lodes was connected directly or indirectly to dikes and sills of intrusive rock, of which the age, when it could be determined, was generally early Tertiary.

158 Rose, T. K.; Newman, W. A. C. The metallurgy of gold [7th ed.]: London, C. Griffin and Co., Ltd., 561 p., 365 references, 1937.

Although this volume is mainly on metallurgy, it includes four chapters on the physical and chemical properties of gold, alloys of gold, chemistry of compounds of gold, and modes of occurrence and distribution of gold.

159 Rosenbaum, Joe B.; May, Joan T.; Riley, J. M. Gold in sea water-Fact or fancy: Soc. Mining Engineers Preprint 69-AS-82, 9 p., 11 references, 1969; Mines Mag., v. 59, no. 9, p. 14-17, 1969.

Reviews history and results of early determinations of gold content of sea water. Present method used by U.S. Bureau of Mines in determining gold content used solvent extraction for initial concentration, evaporation of gold-loaded organic extractant for further concentration, and atomic absorption analysis of gold in the concentrated organic extractant. Sea water now appears to contain about 11 parts of gold per trillion parts of sea water or 0.001 cent's worth of gold per ton.

160 Rowe, J. J.; Simon, F. O. The determination of gold in geologic materials by neutron-activation analysis using fire assay for the radiochemical separations: U.S. Geol. Survey Circ. 599, 4 p., 16 references, 1968.

In this rapid technique for determining gold at the parts-per-billion concentration level, 1-gram samples are irradiated for 10 hours in a flux of $5 \times 10^{12}$ neutrons per square centimeter per second and are allowed to decay for 10 days. The samples are then carried through classical fire-assay separations in the presence of 20 to 50 milligrams of gold carrier, and the gold-198 (half life: 2.7 days) is counted in a gamma-ray spectrometer. Forty samples can be processed in 8 hours, and a detection limit of 0.05 part per billion gold in a 1-gram sample is attainable. (From authors' abs.) 
Ref.

161 Safronov, N. I.; Polikarpochkin, V. V.; Trushkov, Yu. N. Kompleksnyye metody poiskov mestorozhdeniy zolota [Complex methods of prospecting for gold deposits]: Sovetskaya Geologiya, no. 4, p. 92-110, 9 references, 1960; English translation, 30 p. ms.

Reviews the geological, geophysical, and geochemical prospecting methods used for discovering primary and placer gold deposits. The following geochemical methods were found to be useful: gold content survey, tracing dispersion halos of invisible gold in silt-clay fraction of water sediments, use of primary dispersion halos, and hydrochemical and biogeochemical methods. Gold deposits are grouped as quartz-gold ore, sulfide gold ore, deposits of dispersed and interspersed ore, and gold fields. These deposits are described and suggestions are made as to the best prospecting methods to be used for each type.

162 Safronov, N. I.; Polikarpochkin, V. V.; Utgof, A. A. Spektrozolotometricheskaya syemka kak metod poiskov zolotorudnykh mestorozhdeniy ne soprovozhdayemykh mekhanicheskimi oreolami (rossypyami) [Spectrographic aurometric surveying as a method of prospecting for gold ore deposits not accompanied by mechanical halos (placers)], in Novoye metodike i tekhnike geologorazvedochnykh rabot, Sbornik 1: Leningrad, Gostoptekhizdat, p. 100-108, 5 references, 1958; English translation in Internat. Geology Rev., v. 2, no. 3, p. 254-258, 1960.

A combined chemical-adsorption spectrographic method of analysis of metallometric gold samples has a detection limit of $0.03 \mathrm{~g}$ gold per ton or approximately $3 \times 10^{-6}$ percent gold and is also economical for general use. The process involves enriching of a sorbent material with gold from analysis samples. The enriched sorbent is analyzed by a quartz spectrograph. This method was used successfully in the field in Transbaykal by the Russians, where concentration of gold in halos was found to be $0.05 \mathrm{~g}$ gold per ton. It may also be applicable to studying the gold content of plants.

163 Sakharova, M. S. Mineralogiya zolota Darasunskogo mestorozhdeniya (Vostochnoye Zabaykal'ye) [Mineralogy of Darasun gold field in eastern Zabaykal'ye]: Akad. Nauk SSSR Izv., Ser. Geol., no. 11, p. 51-68, 24 references, 1968; English translation in Internat. Geology Rev., v. 11, no. 1, p. 45-59, 1969.

Gold is concentrated in sulfides mainly by selective precipitation from gold-bearing solutions. Gold content decreases from highest in arsenopyrite and pyrite to less in sulfosalt ores and still less in chalcopyrite, pyrrhotite, and galena. Gold crystallization occurs in open cavities and by metasomatic replacement of sulfides. Gold grains, generally pure and containing 84-94 percent gold and 8-16 percent silver, differ by 2-4 percent or more in gold concentrations in margins and cores because of either silver concentration or gold diffusion in sulfides. Gold content increases to depths of 200-400 m but then decreases because of changes in the physicochemical conditions of deposition.

164 Schwartz, George Melvin. The host minerals of native gold: Econ. Geology, v. 39, no. 6, p. 371-411, 118 references, 1944.

Study of the literature and microscopic examination of many ores shows that gold occurs most often in direct contact with the following ore minerals, in order: pyrite, arsenopyrite, galena, sphalerite, ohalcopyrite, bismuth minerals, pyrrhotite and tetrahedrite-tennantite. Most common gangue minerals 
Ref.

are quartz, carbonates, chlorite, graphite and other carbonaceous material, and tourmaline. Many other minerals are occasional hosts. Few minerals are effective precipitants of gold under natural conditions although a host mineral might cause such precipitation. Relations between gold and host. minerals vary, so that each occurrence requires separate study to determinewhich may be guides to gold deposits.

165 Shakhov, F. N. Osnovnyye napravleniya nauchnykh issledovaniy v zolotonosnykh rayonakh Sibiri [Major trends in scientific investigations in the auriferous districts of Siberia]: Akad. Nauk SSSR Sibirsk. Otdeleniye, Geologiya i Geofizika, no. 10, p. 89-101, 23 references, 1961; English translation in Internat. Geology Rev., v. 6, no. 2, p. 202-211, 1964.

Certain questions are discussed pertaining to new problems or new trends in scientific research in the geochemistry of gold and the geology of gold deposits, particularly to the genesis and types of endogenic gold deposits and their relationships to placers and magmatic processes. Special consideration is given in this paper to the examination of the problem of the possible connection between primary deposits of gold and granitic batholiths in regard to the pulsation crystallization of the magmatic melt. (From author's abs.)

166 Shcherbakov, Yu. G. Raspredeleniye i usloviya kontsentratsii zolota v rudnykh provintsiyakh [Distribution and conditions of gold concentrations in ore provinces]: Moscow, Nauka, 267 p., 490 references, 1967; English rev. in Internat. Geology Rev., v. 11, no. 4, p. 511-512, 1969.

Conclusions are based largely on author's gold studies in western Siberia, in Chukotka, U.S.S.R., and in Romania. He systematically analyzed spatial and genetic relationships of endogene gold ore deposits. Topics reviewed are: the geochemistry of gold, distribution of various genetic types of gold deposits, mineral associations, structure of certain gold provinces and position of gold in them, and gold potential of magmatic complexes.

167 Shcherbakov, Yu. G. Zolotorudnyye provintsii i formatsii [Gold ore provinces and formations] in Endogennyye rudnyye formatsii Sibiri $\mathbf{i}$ Dal'nego Vostoka [Endogene ore formations of Siberia and the Far East]: Moscow, Nauka, p. 124-131, 26 references, 1966; English translation in Internat. Geology Rev., v. 9, no. 12, p. 1537-1543, 1967.

Metals associated in gold ore formations are mobilized from volcanic and sedimentary rocks of a geosynclinal series by magmatic and metamorphic activity. Granitic magmas result from refusion of sedimentary rocks. Behavior of metals during the mobilization, transfer, and deposition processes is controlled by their atomic structure and electromagnetic properties. Ionic density and concentration of coefficient of metals may be used as coordinates for plotting the associations of metals in different gold ore formations. Degree of complexity of the associations results from the degree of heterogeneity of the geosynclinal rock series and from the intermittence of the ore-deposition process.

168 Shcherbakov, Yu. G.; Perezhogin, G.A. K geokhimii zolota [Geochemistry of gold]: Geokhimiya, no. 6, p. 518-528, 17 references, 1964; English translation in Geochemistry Internat., no. 3, p. 489-496, 1964.

Gold determinations by radioactivation analysis of 300 samples, mostly from the Altay-Sayan folded belt, U.S.S.R., indicated that the average 
Ret.

gold content decreased from meteorites to ultramafic rocks, from extrusive to plutonic rocks, and from ferromagnesian silicates to feldspars. In a group of igneous rocks, shales and sandstones, and limestones and marbles, the gold content ranged from 0.0032 to $0.010 \mathrm{~g}$ per ton. In the group of igneous rocks carrying anomalous amounts of gold, the gold content ranged from 0.0006 to $0.14 \mathrm{~g}$ per ton. Average gold content in meteorites ranged from 0.067 to $1.15 \mathrm{~g}$ per ton, in ultramafic rocks from 0.0037 to $0.031 \mathrm{~g}$ per ton, and in miscellaneous rock-forming minerals from 0.0038 to $0.077 \mathrm{~g}$ per ton.

169 Shcherbakov, Yu. G.; Perezhogin, G. A. O geokhimicheskoy svyazi zolotogo orudeneniya $\mathrm{s}$ intruziyami $\mathrm{i}$ vmeshchayushchimi ikh porodami $\mathrm{v}$ zapadnoy Sibiri [Geochemical relation between gold mineralization, intrusives, and the enclosing rocks in western Siberia]: Geokhimiya, no. 9, p. 851-858, 14 references, 1963; English translation in Geochemistry, no. 9, p. 882-890, 1963.

Radioactivation analyses for gold in various subphases of granitoid intrusive rocks in west Siberia and in the country rocks surrounding them show that intrusive rocks associated with gold mineralization are found in lower Paleozoic volcanic rocks containing an average of $0.0065 \mathrm{~g}$ gold per ton. Volcanic rocks contain almost twice as much gold as the sedimentary rocks in the section, granites contain the same amount as the sedimentary rocks, and mafic granitic rocks contain more than the younger more silicic types. These gold contents suggest that potentially auriferous magmas form from preexisting rocks with a relatively high gold content. Gold mineralization results from volatiles lost in last phases of magma crystallization and is of ten represented by felsite, rhyolite, and aplite dikes.

170 Shcherbina, V. V. O geokhimicheskom znachenii kolichestvennogo otnosheniya $\mathrm{Ag}-\mathrm{Au}$ [Geochemical significance of quantitative $\mathrm{Ag}-\mathrm{Au}$ ratios]: Geokhimiya, no. 3, p. 65-73, 23 references, 1956; English translation in Geochemistry, no. 3, p. 301-311, 1956[1960].

The accepted silver-gold ratio of the earth's crust is on the order of 20:1 and may be a geochemical indicator for the evaluation of depth, temperature, $\mathrm{pH}$ of medium, and other characteristics of the ore-forming process. Gold enrichment, in general, is observed in higher temperature, deeper seated ore deposits, in older geologic formations, in the more alkaline hydrothermal solutions, and predominantly in telluride ores. Gold is transferred less readily in near-surface processes and is less mobile than silver, as indicated by the higher silver-gold ratio of 37.5:1 in sea water.

171 Shcherbina, V. V.; Zar'yan, R. N. Paragenezis telluridov serebra i zolota, kak mineralov sistemy Ag-Au-Te [Paragenesis of silver and gold tellurides as solid phases in the system Ag-Au-Te]: Geokhimiya, no. 7, p. 635-640, 12 references, 1964; English translation in Geochemistry Internat., no. 4, p. 653-657, 1964.

Parageneses of gold and silver tellurides from Armenia sulfide deposits are described and discussed in terms of the experimentally determined parts of the system Ag-Au-Te. The assemblages hessite-petzite-gold and hessitepetzite-krennerite were formed by deposition from hydrothermal solutions during the galena-sphalerite stage of mineralization and by later replacements. Native silver and tellurium formed by the decomposition of goldsilver tellurides occur in some assemblages. 
Ref.

172 Shilo, N. A. Nekotoryye problemy korennoy i rossypnoy zolotonosnosti [Certain problems of auriferous lodes and placers]: Akad. Nauk SSSR Sibirsk. Otdeleniye, Geologiya i Geofizika, no. 2, p. 3-11, 8 references, 1968; English translation in Internat. Geology Rev., v. 10, no. 11, p. 1241-1246, 1968.

The origins and positions of gold fields, ores, and especially placers in the Yana-Kolyma area and elsewhere in the northeast of U.S.S.R. are reviewed in the light of morphostructural analysis and the behavior of gold in endogenic and exogenic processes.

173 Sidorov, A. A. Epitermal'nyye zoloto-serebryanyye rudoproyavleniya Sopki Rudnoy [Occurrences of gold and silver epithermal mineralization of Sopka Rudnaya]: Geologiya Rudnykh Mestorozhdeniy, v. 7, no. 2, p. 91-96, 4 references, 1965; English rev. in Econ. Geology, v. 63, no. 5 , p. $577,1968$.

Sopka Rudnaya is in the northern part of the Okhotsk-Chukotka volcanic belt. Veins of arsenopyrite-quartz and stibnite-quartz composition cut the the strongly deformed formations of Late Triassic age and wedge out in the Upper Cretaceous volcanic formations. The oldest mineral association is represented by quartz, arsenopyrite, and pyrite. It is followed by the polymetallic association with which gold is connected. Gold (electrum) forms dendritic intergrowths with sulfosalts of silver. The hydrothermal wallrock alteration is characterized by silicification and deposition of adularia. The mineralization is of Paleogene age as indicated by potassium-argon dating. This occurrence of gold-silver mineralization is similar to the numerous occurrences within the Pacific ore-bearing belt. (From English rev.)

174 Sinha, R. K.; Sharma, N. L. World resources of minerals and their strategic importance: Metals and Minerals Rev., pt. 1, v. 6, no. 11, p. 19-28, 1967 ; pt. 2, v. 6, no. 12 , p. 22-28, 1967 ; pt. 3 , v. 7, no. 1, p. 16-28, 1967.

Includes information on worldwide gold occurrences and production.

175 Smith, F. Gordon The alkali sulphide theory of gold deposition: Econ. Geology, v. 38, no. 7, p. 561-590, 42 references, 1943.

After making certain geological and chemical assumptions, it is postulated that the natural solutions which deposit primary gold ores contain alkali sulphide and that the gold is transported as alkali thioaurite. It is shown experimentally that gold is soluble in, and can be crystallized from, such solutions. Two other common gold minerals, electrum (Au, Ag) and calaverite $\left(\mathrm{AuTe}_{2}\right)$, can be similarly synthesized. Other associated features, such as wallrock alteration and associated minerals, are shown to be compatible with the primary postulate. (From author's abs.)

176 Thompson, C. E.; Nakagawa, H. M.; VanSickle, G. H. Rapid analysis for gold in geologic materials in Geological Survey research 1968: U.S. Geol. Survey Prof. Paper 600-B, p. B130-B132, 5 references, 1968.

Trace amounts of gold in geologic materials are determined by atomicabsorption spectrophotometry of an immiscible organic solvent containing the extracted gold. Samples are dissolved by either hot or cold hydrobromic acid-bromine mixtures. In both methods, the gold is extracted from the acid solution with methyl isobutyl ketone which is atomized in an atomicabsorption spectrophotometer for the estimation. The results compare favor- 
Re?.

ably with those from assay methods. Up to 100 samples a day can be analyzed by the cold method and a sensitivity of $0.02 \mathrm{ppm}$ is attained. (From authors' abstract.)

177 Tyurin, N. G. O tonkodispersnom zolote $\mathrm{v}$ pirite [Finely disseminated gold in pyrite]: Geologiya Rudnykh Mestorozhdeniy, v. 7, no. 5, p. 70-75, 23 references, 1965; English rev. in. Econ. Geology, v. 63, no. 7, p. 853, 1968.

Results of experiments to study conditions under which pyrite containing disseminated gold can be formed indicated that such pyrite is precipitated at atmospheric pressure and $95^{\circ} \mathrm{C}$ when $\mathrm{pH}$ drops from 5.6 to 3.5. The gold is deposited simultaneously with the pyrite and represents an impurity in it.

178 Umitbayev, R. B.; Sindeyev, A. S.; Zhupakhin, E. N. K voprosu a poiskakh epitermal'nykh mestorozhdeniy zolota na severo-vostoke SSSR [Prospecting for epithermal deposits of gold in northeastern U.S.S.R.]: Sovetskaya Geologiya, no. 3, p. 131-134, 4 references, 1968; English translation in Internat. Geology Rev., v. 10, no. 7, p. 745-748, 1968.

A very large epithermal gold-quartz vein occurs in subvolcanic trachyliparites of Late Cretaceous-Paleogene age in the Okhotsk-Chukotka volcanogenic belts, U.S.S.R. It is a fissure filling which is unaccompanied by any hydrothermal alteration of the host rocks. The ore minerals in the vein are gold, argentite, hematite, magnetite, limonite, and pyrite.

179 U.S. Bureau of Mines, Field Staff. Production potential of known gold. deposits in the United States: U.S. Bur. Mines Inf. Circ. 8331, 24 p., 91 references, 1967.

Engineering appraisal of more than 1,300 lode and placer gold deposits in the United States determined their production potential. Although their estimated gold content is more than 400 million ounces, only 9 million ounces or slightly more than 2 percent, almost all from Nevada and South Dakota, would be producible at $\$ 35.00$ per ounce under prevailing mining and metallurgical technologies. Any significant increase in the number of economically producible sources would have to come from new discoveries or improved mining and metallurgical techniques.

180 U.S. Geological Survey. U.S. Geological Survey Heavy Metals program, progress report 1966 and 1967: U.S. Geol. Survey Circ. 560, 24 p., 1968.

This review covers the development and projects of the Heavy Metals program for 1966-67 and the discovery of potential gold producers at Carlin, Nev., Cripple Creek, Colo., northwestern Wyoming, and Ely and Northumberland Canyon, Nev. Exploration work in other States and the geochemical phases of the program are briefly described.

181 U.S. Geological Survey. U.S. Geological Survey Heavy Metals program progess report 1968-Field studies: U.S. Geol. Survey Circ. 621, 34 p., 6 references, 1969.

Individual summaries describe briefly the geochemical and geological field studies carried out in 19 States and the special marine studies along the coasts of California, Oregon, Washington, and Alaska and on Pacific and Atlantic Ocean sediments. There is also a bibliography of publications and. of open-file reports completed under the Heavy Metals program in 1968. 
Rer.

182 U.S. Geological Survey. U.S. Geological Survey Heavy Metals Program progress report 1968-Topical studies: U.S. Geol. Survey Circ. 622, 19 p., 5 references, 1969.

Summaries describe briefly the topical studies under the Heavy Metals program for 1968 covering geological, geochemical, and geophysical phases of research, abundance of gold and other heavy metals in rocks, minerals, and organic materials, and development of new analytical methods for detection of gold and other heavy metals.

183 Vakhrushev, V. A.; Dorosh, V. M. Raspredeleniye selena i tellura v sul'fidakh rudnykh mestorozhdeniy Altaye-Sayanskoy oblasti [Selenium and tellurium distribution in sulfide ore deposits of the AltaySayan region]: Geokhimiya, no. 11, p. 1349-1354, 5 references, 1966; English translation in Geochemistry Internat., v. 3, no. 6, p. 10761081, 1966.

Selenium and tellurium have been determined quantitatively in monomineralic sulfide samples from endogene deposits of two genetic types: skarn deposits and vein deposits of gold-quartz ore. Different behavior of selenium and tellurium has been established in both types of deposits. It is proposed to single out deposits of gold-bearing skarns as a separate genetic type or as an independent skarn-gold ore formation. (From Authors' abs.)

184 Vakhrushev, V. A.; Tsimbalist, V. G. Raspredeleniye zolota v sul'fidakh skarnovykh mestorozhdeniy Altaye-Sayanskoy Oblast [Distribution of gold in sulfides of the Altay-Sayan skarn deposits]: Geokhimiya, no. 10, p. 1076-1081, 7 references, 1967; English translation in Geochemistry Internat., v. 4, no. 5, p. 972-977, 1967.

Little exploration has been done on the Altay-Sayan skarn deposits although similar deposits of this genetic type are known to contain economic concentrations of gold. Sulfide minerals in both gold-quartz ore and auriferous skarns are enriched in gold regardless of their time of deposition in the course of sulfide mineral formation. In evaluations of skarn deposits, the gold content in pyrite gives a direct indication of commercial gold mineralization.

185 VanSickle, Gordon H.; Lakin, Hubert W. An atomic-absorption method for the determination of gold in large samples of geologic materials: U.S. Geol. Survey Circ. 561, 4 p., 8 references, 1968.

A laboratory method for the determination of gold in large (100-gram) samples has been developed for use in the study of the gold content of placer deposits and of trace amounts of gold in other geologic materials. In this method the sample is digested with bromine and ethyl ether, the gold is extracted into methyl isobutyl ketone, and the determination is made by atomic-absorption spectrophotometry. The lower limit of detection is 0.005 part per million in the sample. The few data obtained so far by this method agree favorably with those obtained by assay and by other atomicabsorption methods. About 25 determinations can be made per man-day. (Authors' abs.)

186 Vaughn, W. W. A simple mercury vapor detector for geochemical prospecting: U.S. Geol. Survey Circ. 540, 8 p., 10 references, 1967.

The detector utilizes a large-volume atomic-absorption technique for quantitative determinations of mercury vapor thermally released from 
Ref.

crushed rock. A quartz-enclosed noble-metal amalgamative stage, which: is temperature controlled and is actuated by a radio-frequency induction. heater, selectively traps the mercury and eliminates low-level contamination. As little as 1 part per billion of mercury can be detected in a 1-gram sample in a 1-minute analytical period. [Because of the frequent association of mercury as an ore guide to gold deposits, this instrument may become a valuable additional tool in geochemical prospecting programs.] (Author's. abs.)

187 Vikhter, B. Ya.; Razumova, R. V.; Khol', F. I.; Kurbanov, A. Sh. K voprosu o kharaktere zolota $\mathrm{v}$ kolchedannykh mestorozhdeniyakh. [The form of gold in pyrite deposits]: Akad. Nauk SSSR Doklady, v. 178, no. 2, p. 432-433, 4 references, 1968; English translation in Acad. Sci. USSR Doklady, Earth Sci. Sec., v. 178, nos. 1-6, p. 152, 1968.

Gold is almost ubiquitous in pyrite deposits associated with spilite and keratophyre but of ten does not exceed a few grams per ton. The presence of high gold concentrations in pyrite appears to date from the polymetallicstage of mineralization. In the Urup deposit of the North Caucasus, gold content in pyrite increases with increasing copper and lead content; the values were highest in bornite ore, in which the gold contained 85.43 percent gold and 8.99 percent silver. Much emphasis has been placed on thetheory that gold placers cannot form from gold pyrite deposits. In the case of the Urup River placer, however, gold concentrations were found to be. highest below the pyrite bodies of the Urup gold deposit.

188 Vincent, Ewart A.; Crocket, James H. Studies in the geochemistry of gold-[Pt.] 1, The distribution of gold in rocks and minerals of the Skaergaard intrusion, East Greenland: Geochim. et Cosmochim. Acta,. v. 18, nos. 1-2, p. 130-142, 13 references, 1960.

The neutron activation method of analysis was used to determine the gold! content of a suite of rocks in the strongly differentiated gabbroic complex. and in some of the constituent silicate, oxide, and sulfide minerals in the Skaergaard intrusion, East Greenland. Chilled marginal gabbro contained! $0.0046 \mathrm{ppm}$ gold and with four exceptions all rocks and minerals analyzed had! a content between one half and twice this amount. The gold content was. 0.0042 to $0.034 \mathrm{ppm}$ in gabbro with lower olivine content, $0.0024 \mathrm{ppm}$ in middle gabbro, and $0.0031 \mathrm{ppm}$ in hortonolite-ferrogabbro. In constituent minerals the gold content was 0.0013 to $0.0031 \mathrm{ppm}$ in middle gabbro and 0.0018 to $0.0043 \mathrm{ppm}$ in hortonolite-ferrogabbro. The gold showed no preference for any of the various silicate oxide and iron sulfide minerals but was very strongly concentrated in copper sulfides, thus emphasizing the chemical similarity of copper and gold atoms.

189 Vincent, Ewart A.; Crocket, James H. Studies in the geochemistry of gold-[Pt.] 2, The gold content of some basic and ultrabasic rocks and stone meteorites: Geochim. et Cosmochim. Acta, v. 18, nos. 1-2, p. 143-148, 11 references, 1960.

Analyses by the neutron activation method of two Tertiary basalts from Morvern, Scotland, and the Giant's Causeway, Northern Ireland, and of one from Mauna Loa, Hawaii, showed an average content of $0.002 \mathrm{ppm} \mathrm{Au.}$ Similar studies of a dunite from North Carolina, a peridotite from the Isle of Rhum, Scotland, and six olivine-rich nodules in basalts from Europe, Hawaii, 
Ref.

and North America gave 0.001 to $0.01 \mathrm{ppm}$ gold. Four chondritic meteorites from Finland, Ireland, France, and the U.S.S.R. contained an average of 0.1 to $0.3 \mathrm{ppm} \mathrm{Au}$ with 0.74 to $1.5 \mathrm{ppm} \mathrm{Au}$ in their metallic phase.

190 Vinogradov, A. P. Zakonomernosti raspredeleniya khimicheskikh elementov $\mathrm{v}$ zemnoy kore [Regularity of distribution of chemical elements in the earth's crust]: Geokhimiya, no. 1, p. 6-52, 182 references, 1956; English translation in Geochemistry, no. 1, p. 1-42, 1956 [1960].

Examination was made of the gold and other element content in the rocks of 'the earth's crust. With some reservations, the author believes that the gold content may be on the order of $0.001 \mathrm{ppm}$ with an increase in the direction of the mafic rocks to as much as $0.01 \mathrm{ppm}$. Most published gold averages appear to him to be too high, and almost all the six figures he cites here need further checking. The weight percentages he gives are: $1 \times 10^{-5}$ for ultramafic rocks; $5 \times 10^{-6}$ and $1.7 \times 10^{-6}$ for mafic rocks; $3.7 \times 10^{-5}$ and $1 \times 10^{-6}$ for silicic rocks; and $2.5 \times 10^{-4}$ for sedimentary rocks (clays and shales). There seems to be no explanation for the high gold content of the sedimentary rocks.

.191 Vlasov, K. A., editor. Geochemistry and mineralogy of rare elements and genetic types of their deposits-Vol. 3, Genetic types of rare-element deposits: Jerusalem, Israel Program for Sci. Translations, IPST Cat. No. 2193, 916 p., bibliography, 1968; English translation of Geokhimiya, mineralogiya i geneticheskiye tipy mestorozhdeniy redkikh elementov-Vol. 3, Geneticheskiye tipy mestorozhdeniy redkikh elementov: Moscow, Nauka, 860 p., 77 gold references, 1966.

The volume includes sections on the association of rare elements and rareelement minerals, especially $\mathrm{Te}$ and Se, with gold ore deposits, and of gold in telluride and selenide deposits, with examples from various parts of the U.S.S.R. and other countries. It also covers rare-element associations in placers.

192 Voskresenskaya, N. T.; Zvereva, N. F. Nekotorye voprosy geokhimii zolota $\mathrm{v}$ svyazi s rudonosnost'yu magmaticheskikh kompleksov Severnogo Kazakhstana [Geochemistry of gold and its distribution in the magmatic complexes of northern Kazakhstan]: Geokhimiya, no. 4, p. 422-431, 11 references, 1968; English translation in Geochemistry Internat., v. 5, no. 2, p. 373-381, 1968.

The distribution of gold has been studied in three magmatic complexes of different ages and in sedimentary, volcanogenic-sedimentary, and volcanic rocks. Small, but statistically significant differences in average contents of gold are observed for the three magmatic complexes $(1.1,1.6$, and $2.1 \mathrm{ppb}$ gold). Hybrid rocks of the endocontact zones contain 1.5 to 4.5 times as much gold as the granitic rocks. A high gold content $(3.5 \mathrm{ppb})$ is characteristic of rocks of minor intrusive bodies, with which gold mineralization is associated. Possible causes of this enrichment are: (1) assimilation of gold from enclosing rocks and (2) alteration of rocks by postmagmatic solutions. (From authors' abst.)

193 Ward, Hector J. Albite porphyries as a guide to gold ores: Econ. Geology, v. 53 , no. 6 , p. 754-756, 8 references, 1958. 
Ref.

Gold ore deposits related to albite porphyries may be found in silicified albite porphyry, quartz veins in albite porphyry, quartz veins in country rock, or sulfide lodes in country rock. Each type represents a stage in the differentiation of an albite porphyry magma, which may be the end stage differentiate of a basic magma. In the albite porphyry deposits, the gold is commonly associated with pyrite, pyrrhotite, and arsenopyrite with small amounts of chalcopyrite, sphalerite, and galena or scheelite. Sometimes gold tellurides are present. The most striking similarity of the various deposits is the high ratio of gold to silver in the veins. This ratio and the simple mineral associations point to a genetic association.

194 Warren, Harry V.; Delevault, Robert E. Pathfinding elements in geochemical prospecting, in Symposium de exploracion geoquimica, Vol. 2: Mexico, D. F., Internat. Geol. Cong., 20th, 1956, p. 255-260, 3 references, 1959.

Although the gold pan is still a useful tool in prospecting for gold, where gold occurs largely as a telluride, panning below or near the outcrop may not be effective. In such cases, the facts that manganese is associated commonly with epithermal gold deposits and that zinc, in small amounts, is associated with both gold and silver deposits may make them useful as indicator elements. Both manganese and zinc are detected readily in soils, stream silts, and vegetal matter.

195 Warren, Harry V.; Delavault, Robert E.; Barakso, John. The arsenic content of Douglas fir as a guide to some gold, silver, and base metal deposits: Canadian Mining and Metall. Bull., v. 61, no. 675, p. 860-866, 16 references, 1968; Canadian Inst. Mining and Metallurgy Trans., v. 71, p. 205-211, 1968.

Arsenic has been a pathfinder element for many precious metal deposits. Douglas fir (Pseudotsuga menziesii) is an accumulator of high amounts of arsenic, generally 10 to 100 times more than the content in soil and other associated trees and plants. Over the Hedley gold mine, British Columbia, Douglas fir contained $1,165 \mathrm{ppm}$ As and Lodgepole pine and spruce, only 13 ppm As. Douglas fir over the King vein of the Bralorne gold mine contained from 180 to $2,110 \mathrm{ppm}$ arsenic. Douglas fir is widely distributed in western North America and, through its arsenic content, may furnish a new biogeo. chemical prospecting guide for gold, silver, and base metal deposits.

196 Warren, Harry V.; Thompson, Robert M. Minor elẹments in gold: Econ. Geology, v. 39, no. 7, p. 457-471, 5 references, 1944.

Many elements are present in gold ore in minor amounts and vary in gold ore from different districts, which suggests that the differences may be related more to the metallogenic zones or provinces than to the type of deposit. Silver, copper, and iron seem to be present in all samples tested from British Columbia and Yukon Territory, Canada, and from other countries. Other groups of elements, found less of ten and in smaller amounts, are: cadmium and zinc; bismuth and lead; tin, mercury, and zinc minerals, all which are easily recognized; and, as individual elements, platinum, arsenic, vanadium, manganese, and titanium. Spectrographic analysis studies may make it possible to identify the metallogenic province or even the mine, where the gold sample originates. 
Ref.

197 Washington, R. A.; Holman, R. H. C. A rapid and sensitive method for determining gold in rocks and other geological materials: Canada Geol. Survey Paper 65-7, 18 p., 14 references, 1966.

Preliminary tests show the feasibility of using the fire assay method to concentrate gold in a silver bead from silicate rocks for subsequent neutron activation analysis. Following this, no radiochemical separation of gold is needed. Detection limit, using silver as a collector, is about $0.01 \mathrm{ppm}$ Au for a sample weighing one assay ton $(29.2 \mathrm{~g})$. Precision for homogeneous samples is about 1 to 2 percent at $1 \mathrm{ppm}$ falling to about 50 percent near the detection limit. Probable output is 25 to 30 determinations per man-day. Suggested additional new techniques may lower the detection limit by a factor of ten.

198 Wells, John D.; Stoiser, Lee R.; Elliott, James E. Geology and geochemistry of the Cortez gold deposit, Nevada: Econ. Geology, v. 64, no. 5, p. 526-537, 14 references, 1969.

Gold was discovered at Cortez in dolomitic limestone and siltstone in the upper part of the Silurian Roberts Mountains limestone and is disseminated in a large zone where rocks have been fractured and bleached and the pyrite oxidized. It occurs in micron-sized particles of native gold mostly with silica between original silt grains or, less often, in quartz-filled microfractures and hematite-goethite pseudomorphs after pyrite and was probably carried by hydrothermal solution from igneous rocks nearby. It is associated with an As-Sb-W-Hg geochemical anomaly, a typical feature of other gold deposits in the area.

199 White, William $\mathrm{H}$. The mechanism and environment of gold deposition in veins: Econ. Geology, v. 38, no. 6, p. 512-532, 5 references, 1943; discussion by W. James Bichan, v. 39, no. 3, p. 234-241, 1944.

A study of hypothermal, mesothermal, and epithermal gold ores from 27 districts which represented the main types of gold deposits in the United States and Canada showed that a number of characteristic features were common to almost all the deposits. The process of cataclasis, that is, the minute fracturing and almost contemporaneous recrystallization of quartz in gold veins, is considered an important factor in allowing residual solutions to permeate the quartz and distribute the gold. Vacuoles in vein quartz aid this deposition. In general, gold was deposited from mobile residual solutions under uniform conditions of low or waning stress at temperatures possibly less than $200^{\circ} \mathrm{C}$ even though the initial temperature of the quartz veins may have been high.

200 Wilson, Harry D. B. Geochemical studies of the epithermal deposits at Goldfield, Nevada: Econ. Geology, v. 39, no. 1, p. 37-55, 3 references, 1944.

Spectrographic examination of about 50 ore samples of vein and wallrock indicated that bismuth, silver, and tin are genetically associated with gold values in the deeper veins and can be determined even in very low-grade vein material. Quantitative variation of some elements in wallrock may help determine the distance of a given wallrock from a vein.

201 Wrucke, Chester T.; Armbrustmacher, Theodore J.; Hessin, Thomas D. Distribution of gold, silver, and other metals near Gold Acres and Tenabo, Lander County, Nevada: U.S. Geol. Survey Circ. 589, 19 p., 8 references, 1968. 
Rof.

Geochemical investigations on the east flank of the Shoshone Range showed two well-defined belts of anomalous concentrations of antimony, arsenic, bismuth, cadmium, copper, gold, lead, mercury, molybdenum, silver, tin, tungsten, and zinc. Gold is enriched in the eastern parts around a granodiorite stock which contains from less than 0.1 to more than $10 \mathrm{ppm}$ $\mathrm{Au}$ and on the flank of a magnetic anomaly thought to represent a buried stock at Gold Acres.

202 Zul'fugarly, D. I. Verbreitung der Spurenelemente in Kaustobiolithen, Organismen, Sedimentgesteinen und Schichtwässern [Distribution of trace elements in caustobioliths, organisms, sedimentary rock, and ground water]: Leipzig, VEB Deutscher Verlag f. Grundstoffindustrie, 291 p., 741 references, 1964; German translation of Rasprostraneniye mikroelementov $\mathrm{v}$ kaustobiolitakh, organismakh, osadochnykh porodakh i plastovykh vodakh: Baku, Izdatel. Azerbaydzhan. Univ., 230 p., bibliography, 1960; English abs. in Bibliography and Index of Geology exclusive of North America, v. 28, p. 633, 1963.

This German version of the Russian book reviews the history and gives the bibliographic references for reported trace amounts of gold and other elements in ash from petroleum, coal, and tissues of organisms, and in sedimentary rocks and sea water.

203 Zvyagintsev, O. E. Concerning the action of minerals on gold solutions: Acad. Sci. URSS Comptes Rendus (Doklady), v. 21, no. 4, p. 176-178, 2 references, 1938.

Gold in gold chloride solutions is precipitated by sulfide minerals at varying velocities, namely, slowly by galena and sphalerite and rapidly by iron-bearing sulfides, such as pyrite, chalcopyrite, and arsenopyrite. An increase in the room temperature or in the sulfide surface also increases the rate of gold precipitation. In the case of red colloidal gold solutions, pyrite causes all the gold to settle in a few minutes, galena and sphalerite each cause it to settle in 24 hours, whereas chalcopyrite causes it to settle in 48 hours.

204 Zvyagintsev, O. E. Geokhimiya zolota [Geochemistry of gold]: Moscow, Akad. Nauk SSSR, 114 p., 56 references, 1941; English translation by V. P. Sokoloff, 127 p., 1949.

This review of the geochemistry of gold includes chapters on the following topics: properties, physical and chemical, of gold; gold alloys; behavior in metallurgical processes; gold in coal, plants, and meteorites; gold minerals (native through tellurides); accumulation processes; types of gold deposits; accumulation from crystallization of acidic and basic magmas; processes in the oxidized zone of gold particles; formation of placers and dissipation of gold; and the gold cycle in nature. 


\section{AUTHOR INDEX}

A

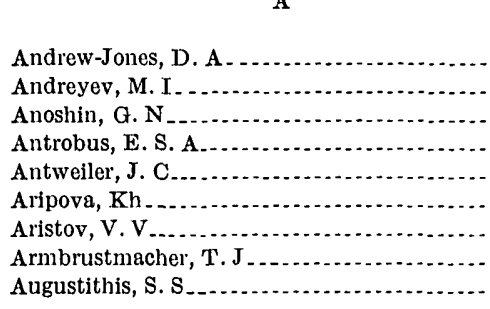

\section{B}

Badalov, S. T.

Badalova, R. P

Barakso, $\mathrm{J}$.

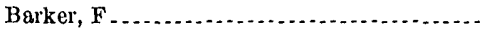

Barnett, P. R.

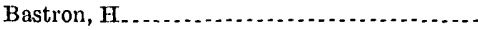

Bateman, A. M

Beamish, F. E

Beevers, J. R.

Berg, H. C.

Bergendahl, M. H

Bichan, W. J

Bilibin, Yu. A

Borovitskiy, V.P

Borozenets, N. I.

Botbol, J. M.

Bowen, H. J. M

Boyle, R. W

Brokaw, A. D.

Bronshteyn, B. M

Brooks, H. C.

Brownlow, A. H.

Bugel'skaya, L. V

Buryak, V. A

Butler, J. R.

c

Cabri, L. J

Cannon, H. L

Chamber of Mines Journal .

Chao, T. T.

Chernyayev, A. M

Chernyayeva, L. E

Chow, A

Chukhrov, F. V

Cieslewicz, J

Clark, A. L

Clark, S. H. B

Clifford, T. N

Ref.
1
37
2,150
3
4
5
117
201
6
Clifton, H. E..........

Cloke, P. L_.......................... 45, 109, 137

Cobb, E. H.......................... 15, 46, 47:

Coetzee, F . . . . . . . 48

Condon, W. H. . .............................. 40 ,

Crawford, T. J . ........................... 100

Crocket, J. H. . . . . . .................. 49, 188, 189 .

Curtin, G. C.............................. 50 ,

Davidson, C. B . . ......................... 51, 52 *

Davidson, C. F . ........................ 117 .

DeGrazia, A. R

Delevault, R. E.......................... 194, 195 .

Denisov, S. V .............................. 54،

Dorosh, V. M . .................................. 183:

Dougherty, E. Y............................ 133 :

Douglas, J. S................................ 55

Dvornikov, A. G...................... 56, 57

E

Eales, H. V

Elliott, J. E $\mathrm{E} \ldots \ldots \ldots \ldots \ldots \ldots \ldots$

Emmons, W. H. . . . . . .

Epshtein, Yu. A ......................... 61

Erickson, R. L.............................. 62 :

Erikson, J. E............................. 63

Ewers, W. E. ..................................

F

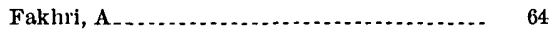

Fayzullin, R. M.......................... 65

Ferrians, O. J., Jr ..........................

Firsov, L. V................................. 66

Fischer, R. P.

Fisher, F. S .........

Fitzgerald, A. C............................ 68.

Fleischer, M................................ 105.

Fortescue, J. A. C.......................... 69.

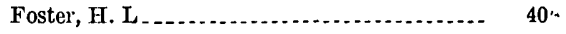

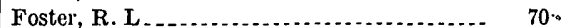

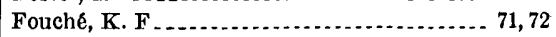

Frondel, C................................ 73 :

Galkin, M. A............................. 74

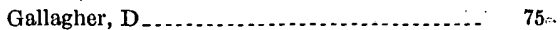

Garrels, R. M............................ 98

41 Garrett, R. G.............................. 76. 


\begin{tabular}{|c|c|c|c|c|c|c|c|c|}
\hline & $\begin{array}{l}\text { Gay, N. C } \\
\text { Ginzburg, V. L } \\
\text { Gmelin, L. } \\
\text { Goleva, G. A. } \\
\text { Goni, J. } \\
\text { Goodwin, A. M } \\
\text { Gott, G. B. } \\
\text { Graham, R. J } \\
\text { Green, T. E. } \\
\text { Gross, W. H. } \\
\text { Grout, F. F. }\end{array}$ \\
\hline
\end{tabular}

H

Haber, $\mathrm{F}$

Hagen, J. C

Harbaugh, J. W

Haskin, L

Hausen, D. M

Hawkes, H. E.

Hawley, C. C.

Helgeson, H. C

Heppting, L. M

Herdrick, M. A

Hessin, T. D

Hoare, J. M.

Holman, R. H. C

Hsieh, $\mathrm{S}$

Hubert, A. E

Huffman, C., Jr

Hunter, R. E

Hurst, V. J

J...

-...-

Ref.

Kurbanov, A. Sh........

Kuvichinskiy, V.V........................ 117

L

Lakin, H. W...................... 50, 118, 124, 185

Law, S. L................................ 119

Learned, R. E........................... 126, 127

Legedza, V. Ya . .......................... 120

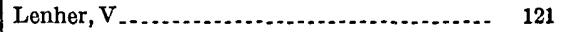

Leong, K. W

1 Lesure, F. G............................. 110

Lincoln, F. C. . ............................. 122

Lodder, W. . . . . . . . . . . .

Love, J. D. . ............................... 4

88,89 Lovering, T. G........................... 124, 126

Luttrell, G. W............................... 125

M

McCarthy, J. H., Jr_............... 62, 83, 84, 126, 127

McCauley, C. K. ........................ 128

McConnell, G. W........................... 23

Machairas, G............................ 129, 130

McHugh, J. B ............................ 84

Mackay, R. A . ........................... 131

MacKevett, E. M. . ....................... 132

7 McKinstry, H. E................................ 133

49 MacLaren, J. M. . ......................... 134

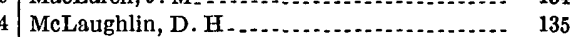

Mantei, E.J................................ 136

4 Marinenko, J . . .

100 Markham, N. L_........................... 137

Markward, E. L............................ 52, 138

Martinet, R_............................. 149

Martinez, E. E............................. 97

Masson, D. L . . . .

Matson, N. A., Jr. . ....................... 155

Mattick, R.E................................. 151

May, J. T ................................. 159

106 Mazzuchelli, R. H............................ 140

Mensik, J. D . ............................... 99

Merwin, R. W............................... 141

Meuschke, J. L............................. 127

Miller, A. D .............................. 17

Miller, T. P............................. 142

Moore, G. W................................. 143

Moore, $\mathrm{L}$..................................... 144

Murdoch, J.................................. 145

Murovtsev, A.V............................. 148

Keays, R. R ................................ 49

Kelly, w. C................................. 45, 109

Kerr, P. F................................. 92

Khmelevskaya, N. M._.................. 33

Khol', F. I. ...

Kinkel, A. R., Jr........................ 110

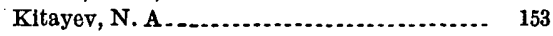

Kogen, V. B............................. 111

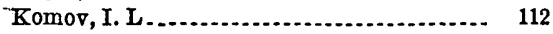

Korolev, V. A.............................. 113

Koroleva, N. N............................ 113

Koschmann, A. H........................... 114, 115

Koshman, P. N ........................... 54

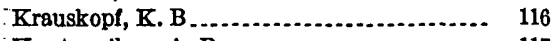

Krestovnikov, A. B . .................... 117

Kreyter, V. M.

8

N

Nakagawa, H. M...................... 62, 118, 176

Narayanaswamt, S........................... 146

Neuerburg, G.J....................... 50

Newman, W. A. C........................ 158

Nichol, I................................... 76, 147

\section{0}

Ohle, E. L., Jr................................... 133

Oliver, H. M............................. 151
Ovechkin, V.V............................... 113 
$\mathbf{P}$

Paley, L. Z.

Parès, $\mathrm{Y}$.

Perel'man, A. I.

Perezhogin, G. A.

Peshchevitskiy, B. I.

Petersen, U...

Peterson, D. W.

Phillips, R. L

Pings, $W . B$

Polikarpochkin, V. V

Potap'yev, V.V $153,161,162$

Ramp, $\mathrm{L}$

Razin, L. V.

Razumova, R.V.

Richter, D. H.

Rickard, T. A

Riley, J.M.

Rlley, L. B.............................. 99

Rogover, G. B ............................ 78

Rose, T. K............................. 158

Rosenbaum, J. B . ......................... 159

Rowe, J. J.

Rozhkov, I. S.

Rucklidge, J. C.

Safronov, N. I

Sakharova, M. S .

Sandy, J

Sarapulova, V. N

Sarcia, C

Schwartz, G. M

Shacklette, H. T

Shakhov, F. N.

Sharma, N. L.

Shcherbakov, V. P.

Shcherbakov, Yu. G

Vincent, E. A........................... 188, 189

Vinogradov, A. P....................... 130.

Vlasov, K. A............................ 191

Volynski1, I. S . ............................ 117

Voskresenskaya, N. T.................... 192 .

W

161, 162 Ward, H. J............................. 193

163 Warren, H. V............................ 194-196.

100 Washington, R. A......................... 197

153 Watterson, J. R . .......................... 126

81 Webb, J. S..................................... 94

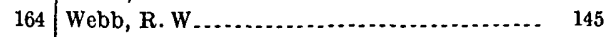

35 Wells, J. D ................................ 59, 198.

165 White, W. H.................................... 199

174 Wilson, H. D. B.......................... 200.

57 Wise, E. M................................ 135

166-169 Wrucke, C. T............................ 201

Shcherbina, V. V.......................... 170, 171

Shemyakin, V. N. . . .

Shilo, N. A................................. 172

Sidorov, A. A . .............................. 173

Silver, E. A.............................. 143

Simon, F. O

Sindeyev, A. S............................ 178

Sinha, R. K.............................. 174

Skinner, D. L.............................. 12

Smales, A. A.......................................... 71

Smith, F. G.............................. 175

Smith, J. G............................. 132

Sokoloff, V. P............................... 204

Stotser, R. L. ............................. 198

Stumpfl, E. F............................ 58

Swanson, F. J

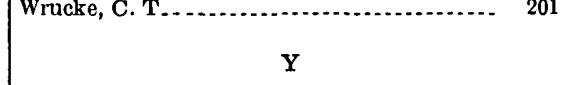

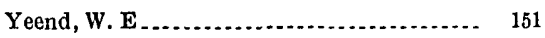

Yeremeyeva, M. N....................... 37

Yerenburg, A. M......................... 150 .

Yugay, T. A........................... 54

Zablocki, C. J............................... 85 .

Zar'yan, R. N............................... 171

Zhupakhin, E. N. . ....................... 178

Zul'fugarly, D. I. .......................... 202.

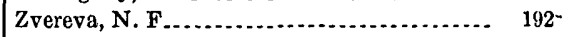

Zvyagintsev, 0. E . ................... 117, 203, 204. 
4

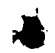




\section{SUBJECT INDEX}

A

Abundance, altered zones. coal.

colluvium, cobbles $20,202,204$ pebbles earth crust........................ 1, 53, 104, 190 glacial drift igneous rocks $1,20,78,90,103,122,166,167,168,169$ basalts.

diabase. 160,189 diorite $-2=0$

dunite........................... 189

felsic .....................................

gabbro.............................. 188

granite........................ 2, 142, 160

granodiorite........................ 201

hortonolite-ferrogabbro.............. 188

mafic.............................. 1, 190

magmatic complexes.................. 192

peridotite............................. 189

silicic................................ 190

ultramafic . ..................... 1, 168, 190 volcanic.

lodes.................................... 132

metamorphic rocks .................... 103, 166 jasperoids ........................... 124, 126

metasedimentary rocks, phyllite quartzite.

104,166, 168,204 chondrites.............. 49, 72,167, 168, 189 iron ........................... 71

minerals................................ 168, 188

biotites............................ 138

feldspar............................ 2

hornblende........................ 136

magnetite .

quartz ............................ 2

quartz-feldspar offshore deposits, Continental Shelf, Oregon.

Continental Shelf, Oregon-California ore deposits, mercury ....... organic matter 19,202 petroleum.............................. 202 plant............................ 79, 102, 204

plant ash, algae angiosperms

ferula .

horsetail (Equisetum)

Kuranakh area, U.S.S.R

saltwort_. wormwood

rocks. sedimentary rocks $20,103,122,166,167,202$ quartzite conglomerate, wyoming ... 4

sediments, marine $42,43,79,143$ stream . .................... 40, 132, 142, 155

soils, mull, humus-rich forest soils ......... 50 ore-free zone cover ................... 5 ore zone cover . ...................... 5

water, ground . . .......................... 37, 102 pit waters in mines . . ................. 17 river.............................. 20, 102 sea .........20 20, 79, 88, 89, 102, 122, 150, 159, 202 springs .............................. 102 springs in gold mines streams. streams near mines . ................. 17 thermal springs . . ................... 79

Africa, metallogenic provinces, cratons . ....... 41 production .............................. 41 resources, cratons........................ 41

Alaska, central Alaska range.................. 96 central Koyukuk River.................... 142 McCarthy area McGrath area

Red Devil area . ........................... $\quad 35$ resources, lode gold deposits............... 15 lodegold deposits, map . . ............. 15,46 placer gold deposits, map ............. $\quad 47$ potential, Livengood district.......... $\quad 70$ Sikonsina Pass .......................... 40 Slana area................................. 155 upper Chulitna district................... 95 Albite....................................... 75, 193

Alteration, adularia deposition.............. 21,173 albitization............................. 21, 148 alunitization ......................... 175 beresitization........................ 31, 111, 192 bleaching............................... 198 carbonitization. ......................... 21, 31 hydrothermal ........................... 2 muscovitization......................... 2 oxidation .............................. 26, 198 propylitization . ............................ 31, 192 pyritization . ........................ 21, 175, 198 sericitization........................... 31, 148 silicification................ 21, 31, 74, 133, 148, 173 wallrock. . .... 21, 31, 74, 111, 123, 133, 173, 175, 192 zonation . . . . . . . . . ....................... 30,123 Analyses, mercurous chloride layer........... 101 precision ............................... 44 required sample size..................... 44 Ash, animal.......................... 20,79, 102 plant...................... 5, 20, 35, 102, 154, 204 Atlantic Ocean, north polar seas............ 89 southern part............................ 88, 89 
Atomic-absorption technique. See Spectrophotometric investigations.

\section{B}

Bibliographies, geochemical prospecting...... geochemical prospecting, abstracts . .......

resources, California

United States, Heavy Metals program 1968

Biogeochemical prospecting, bacterial leaching

history.

principles

scope.

techniques

trees as guides

Brazil, Jacobina, Canavieiras mine..........

British Columbia

Bralorne gold mine......................

Hedley gold mine

Watson Bar creek.

C

California, Mother Lode belt.

Nevada County

resources, bibliography

resources, bode

potential ............................. 141

Tertiary gravel-filled channels ....... 141,151

Canada, resources....... 23, 55, 68, 82, 97, 195, 196, 199

vein deposits.

199

Carbonate rocks.

Chemical-adsorption technique. See Spectrographic analysis.

Chemical properties. ..................... 158, 204

Colloidal gold, effects of colloidal silica........ 73

experimental studies..................... 94

genesis .................................. 92

precipitation rate..................... 203

role in ore formation .................... 92

stability .............................. 73,81, 94

suspension studies....................... 81

transportation........................... 73

Colorado, Cripple Creek district............. 84, 118

Cresson mine area 84

Needle Mountains, Precambrian conglomerates.

Silver Mountain

Composition, atomic structure

chemical forms in sea water

minerals, auriferous

native gold

Continental Shelf, Oregon.

Oregon-California.

D

Descriptions, geochemical . $23,76,90,94,204$

Determination methods, fire assay
$\mathbf{E}$

Ref.

165,166

Endogenesis

Epigenesis................................ 24, 92,96

Epigenetic mineral deposits . . . . . ........... 24,92,96

Ethiopia, Onodonoc........................

F

Fiji Islands, Vatakoula deposits .............. 137

Fineness, color as index . ................... 105

degree................................... 9, 107

divergence in native gold ................ 131

grain-size effect........................ 105

guide to temperature of ore formation .... 105 .

increase with increased grade............. 105

relation to sulfides....................... 58

relationship in hypogene deposits......... 58

Fire-assay technique, description............. 12

laboratory detection limits................. 12

materials tested ............................. 12

G

Genesis, alluvial origin...................... 3

cataclastic effects........................ 199

direct volcanic theory ................... 82

effects of metallogenetic relationships..... 16 .

enrichment, primary . .................. 156

secondary .............. 87, 110, 117, 148, 156

epigenetic gold-quartz veins ............... 23

grain-size relationship..................... 48

hydrothermal. . $33,66,82,98,106,107,133,173,200$

in carbonate rocks..................... 113

low-temperature solutions................. 199

ore shoots . . . .

placers.............................. $32,86,187$

pyrite deposits....................... 177, 187

skarns................................. 183

structure relationship ................... 172

sulfide content........................... 167

sulfide deposits.......................... 117

syngenetic gold-alunite veins . . . . . . ....... 123

supergene transport....................... 110

Geochemical prospecting, applications........ 22 bibliographies........... 29, 51, 52, 63, 91, 138 biological. See Biogeochemical prospecting. epigenetic mineral deposits, future exploration............................. 24

host rocks............................. 24

mode of transport.................... 24

precipitation mechanism............. 24

source............................... 24

future research problems................... 22

Heavy Metals program................ 180,181

history ............................... 22

India, soil samples . . ..................... 146

indicator elements, arsenic... 1, 21, 146, 147, 195

copper........................... 111

galena............................. 111

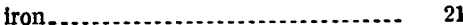

manganese.......................... 194

mercury................. 56, 57,97, 127, 186 
mical prospecting-Continued

indicator elements-Continued

sllver

sulfur...

tellurides.

zinc

indicator plants................... 35, 139, 154

instruments, mercury detector . .......... 186

methods. .. 93,94

ore guides, albite

anomalous concentrations of metals other than gold ........ 70,85,97, 198, 201 anomalous gold concentrations........ 5 , $50,59,62,70,95,96,142,155$

antheaps arsenic. ................. 76, 140, 146, 195, 198 carbonates

correlation indices.

galena.

gnoissic domes.

- 64

gold halos. 61

gold-silver ratio

$5,83,153$

halos of other metals. .. $56,57,64,80,111,153$

hydrogeochemical ................... 3,7

magnetic anomalles. ................ 27

mercury.................... 56, 57, 97, 127, 186

pan concentrates..................... 67

quartz veins........................ 98

trace element content . . ............... 196

trees................................ 55

principles............................... 1,93,94

stream sediment sampling............. 67,95,96

techniques............................ 1,161

Georgia, resources, central Savannah River

area. . ....................... 100

Glossary . ................................... 1

Greenland, East, Skaergaard intrusion....... 188

\section{$\mathbf{H}$}

Heavy Metals program

$180,181,182$

Host minorals, quartz

sulfides.

variation in relationship.................. 164

Host rocks, relationship to intrusions....... 165, 169

Fypogenic transport........................ 66

\section{I}

Igneous rocks....1, 20, 78, 90, 103, 122, 166, 167, 168, 169 See also Abundance.

India, Kolar gold flelds, geochemical prospecting

Ion-exchange technique, description........... laboratory detection limits..................

materials tested.

Ivory Coast, Ity

I

Lode deposits..... 15, 46, 114, 115, 125, 132, 157, 165, 166 $\mathbf{M}$

Magnetite
Maps, mineral resources, Africa Ref. mineral resources, Alaska, lodo........... 15,46

Alaska, placer....................... 47

United States....................... 114

Virginia............................. 125

Matine sediments....................... 42, 43, 79, 143

Metallogenetic relationships................... 16

Metamorphic rocks......................... 103, 166

Metasedimentary rocks. See Abundance.

Meteorites. See also Abundance... 104, 166, 168, 204

Migration, colloidal hypogene solutions...... 66 compounds.............................. 80 effects of differences in capacity............ 64 ground water......................... 37, 80 oxidation zone......................... 39, 117

types...................................... 204

Mineral associations ................... 1, 13, 77, 204

albite.................................... 75, 193

alloys................................... 158

arsenic ............................ 76, 105, 122, 198

chalcopyrite ............................ 7,78

galena................................... 111

it on meteorites......................... 71

iron oxides

manganese.............................. 194

mercury.................... 56, 57, 74, 83,84, 97

polymetallic .............. 1, 85, 111, 196, 198, 200

pyrite............. 6, 7, 48, 74, 113, 129, 177, 187

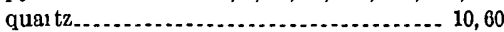

selenides.................................. 105, 122

silver...... 23, 68, 83, 84, 111, 130, 170, 171, 193, 200

silver-gold ratio............. 8, 21, 68, 111, 170, 193 sulfides.................................. 1 ,

$10,23,31,50,66,77,78,87,92,105,107,111$, $122,163,164,166,167,178,193$

tellurides...... 34, 83, 84, 105, 107, 122, 137, 166, 171 trace element content. . .............. 54, 191, 196 uranium.................................. 48

volcanic rock sequences.................. 82

zinc ..................................... 194

Mobility . ............................... 1,45

Montana, Marysville quar tz diorite stock..... 136

\section{$\mathrm{N}$}

Native gold, colloidal, stability .............. 81,94 common mineral associations............. 105 composition.............. 77, 81, 94, 105, 167, 187

Neutron activation method, advantages...... 38 comparisons............................ 38 description.............................. 38, 160, 197 detection limits, laboratory.............. 160, 197 materials tested.......................... 160 output per day........................... 160, 197 precision................................ 197

Nevada, Carlin mine......................... 92 Cortez district........................ 62, 127, 198

Ely.................................. 83

Getchell mine........................... 106

Goldfield................................... 200

Lander County, Sheep Creek range...... $\quad 85$

Mill Canyon............................. 59

production, potential resources........... $\quad 179$

New Mexico, Picuris Range.................. 11

Tusas Mountains.......................... 11

Northwest Territories, Yellowknifo district.... 23 


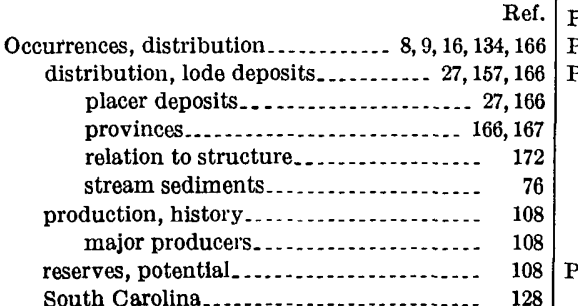

types....................... 1, 10, 77, 134, 161, 204

albite. . . . . . . . .

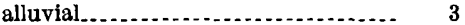

carbonate rocks . ................ 113

classification . . ..................... 134

conglomerate. ............... 21, $48,65,86$

deposits in fracture systems............. 135

disseminations........... 7, 30, 112, 135, 177

distribution .................... 9,134

epigenetic gold deposits . . . . . . . . 24, 24,96

genesis. . . . . . . . . . . 204

gold-quartz veins ........... 21, 30,46, 66, 100,

$111,112,114,115,156,165,178,193$

gold-sulfide deposits. . . . . . . . . . 46, 113, 114

$115,117,165,193$

hydrothermal deposits ................ 33 $82,98,106,107,133,173,200$

lode deposits. $15,46,114,115,125,157,165,166$. magmatic complex.................. 192 mechanical concentrations............ 135 placers . - 10, 21,47,65,100,114,115, 135, 165, 166 polymetallic...................... 96, 173 replacement. . . . . . . . . . . . . . 133, 135 residual concentrations.............. 135 saprolite deposits . . . . . . . . . . . . . . 100 siliceous replacement................ 135 skarn .......................... . 21, 183, 184 sulfide replacement.................. 135 sulfides................... 30, 111, 113, 117, 193 Tertiary gravel-filled channels...... 141, 151

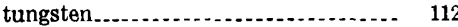

United States, principal producing districts.

principal producing districts, map

types.............................. 115

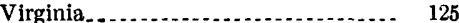

world, classification................. 13, 60, 135

descriptions . . . . . . . .

distribution . ................... 60, 158

major deposits .................... 13, 135

types............................ 13,60,158

Ontario, Birch-Uchi lakes area . ............ 82, 97

Oregon, Blue Mountains . . ................. 28

Brookings to Coos Bay . . . . . . . . . . 43

Cape Arago to Cape Sebastian ........... 42

Klamath Mountains..................... 28

resources ............................... 28

Western Cascades ........................ 28

$\mathbf{P}$

Pacific Ocean, Continental Shelf ......... 42, 89, 143

Paragenesis, gold-quartz-tourmaline veins . . . - 6 gold-silver tellurides............... 34, 137, 171 order of crystallization.................. 171
Ref.

Physical properties..................... 158, 204

Plant ash . . . . . . . . . . . . . . $5,20,35,154$

Precipitation, agents ........................ 204

effect of alkaline sulfide solutions...... 121, 175

effect of recrystallization.................. 130

effect of reduction. . . . .................. 129

effect of sulfides

effect of temperature. . . . . . . . . . . . . . . 98, 203.

secondary agents .

Production, Nevada, potential resources...... 179

South Dakota, potential resources........ 179

United States, potential resources . ....... 179

Purity, criterion of secondary enrichment .... 131

effect of sulfides

\section{Q}

Quebec, Val d'Or

$\mathbf{R}$

Rhodesia, Blanket mine.

$\mathbf{S}$

Sea water. See Abundance, water.

Sedimentary rocks. See Abundance.

Sierra Leone, eastern...................... 76

Sula Mountains-Kangari Hills............ 147

Soils. See also Abundance

arsenic anomalies.... 146

Solubility, acidity effect..............

bacterial effect . . . . . . . . . . . . . . . 149, 151

chloride ion effect . . . . . . .

effect of alkaline sulfide solutions. _ _ 116, 121, 175

ferrous salts. ............................ 26

manganese dioxide....................... 26

near-surface environment. ............... 109

oxidation ................... 26, 45, 109, 129, 130

pressure changes . ....................... 116

sulfide oxidation............... 130

surface alteration......... 26

temperature changes. .................... 116

theories and current studies

Solvent-extraction technique. See Spectrophotometric investigations.

South Africa, Republic of, Transvaal, Bushveld Complex.

Witwatersrand, Basal Reef

Witwatersrand, Central Rand gold field..

distribution ..................... 48

genesis

South Carolina, resources . . . . . . . . . . . . . . . 128

South Dakota, production, potential re-

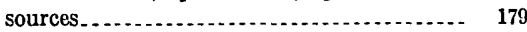

Spain, Rodalquilar area..................... 123

Spectrochemical technique, description....... 12

laboratory detection limits.............. 12

materials tested ........................ 12

Spectrographic analysis, chemical-adsorption technique, laboratory detection

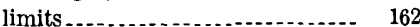

chemical-adsorption technique, description. 
Spectrophotometric Investigations, atomicabsorption technique, description. 14 $99,118,119,124,159,176,185$ atomic-absorption teshnique, interference factors. 118,176 laboratory detection limits........... 14, $99,118,124,176,185$

materials tested 118

output per day $119,124,159,176,185$ $119,176,185$ principal reagents..... 14, 99, 118, 119, 176, 185 solvent-extraction technique, description .. 14,99

laboratory detection limits............ 14,99

principal reagents..................... 14, 99

Stability, alkaline sulfide solutions.......... 121 colloidal, experiments..................... 81, 94 in weathering zone. Stream sediments................. 40, 132, 142, 155 Supergenic transport.

Syngenetic deposits.

110

S

\section{$\mathrm{T}$}

Texture, types $6 ; 31,163$

Transportation, agents. alkaline sulfide solutions 121,175 cycle in nature hydrothermal solutions

thermodynamic requirement thiosulfate carrier.

\section{U}

United States, bibliographies, Heavy Metals program.

conterminous....................... 35, 114, 115

Heavy Metals program.............. 180, 181, 182

production, potential resources........... 179 resources, mineral resources map........... 114

principal producing districts........ 114, 115

types.................................. 115

vein deposits........................ 199

southeast........................... 110

west..................................... 124

U.S.S.R., Aldan_.......................... 17, 18

Almalyk ........................... 7

Altay ..................................... 2

Altay-Sayan............................ 183, 184

Amur................................. 54

Armenian S.S.R....................... 171

Darasun gold field........................ 163

Donets Basin ............................ 56

Kamenskoye gold field................. 65
U.S.S.R.-Continued Ref.

Karamazar............................ 8

Kazakhstan....................... 64,117, 192

Kolyma River basin..................... 27

Kuranakh area......................... 154

Lena gold fields . . ...................... 30, 31, 32

Maikan.............................. 117

middle Asia . ........................... 113 .

Nagolnyi Range.......................... 57

Noril'sk ................................. 78 .

Okhotsk-Chukotka volcanic belt....... 173, 178 .

Patom highlands....................... 33

Primor'ye.................................. 61

Russian platform..................... 120 .

Siberia.................................. 165, 169

Stanovoy Range........................ 111

Sultanuizdag........................... 148

Tamdynsk Mountains....................

Transbaykaliya ........................ 2, 153

Transcaucasia.......................... 107

Ural Mountains........................ 117

Urup gold deposits...................... 187

Uzbekistan............................. 8,9,10

Yakutia................................. 74

Yana-Kolyma region................... 66, 172 .

Yenisey Range........................ 112 .

Utah, Drum Mountains.................... 126 .

\section{V}

Virginia, resources, lode deposits . . .......... 125 . resources, mineral resources map.......... 125 . placer deposits....................... 125 .

\section{W}

Water. See Abundance.

Western Australia, Kalgoorlie................. 137 .

laterites....................

World, resources, classifications............ 13, 60, 135 resources, descriptions................. 13,60,174

distribution ....................... 60, 158 .. major deposits....................... 13,135 .

major producers..................... 108.

production history................... 108

production $d_{\text {otential }} \ldots \ldots \ldots \ldots \ldots . . . . . . .174$

types.............................. 60, 77, 158 .

reserves, potential.................... 108.

Wyoming, northwest part . ................ 4

\section{$\mathbf{Y}$}

